\title{
A kereskedők fizetésikártya-elfogadása Magyarországon az online pénztárgépek adatai alapján*
}

\author{
Ilyés Tamás - Varga Lóránt
}

Tanulmányunkban a fizetési kártya elfogadását vizsgáljuk a magyar kiskereskedelmi szektorban a számlaszintü, részletes online pénztárgép adatbázisa alapján. Kutatásunk fö célja az elsődleges magyarázó változók azonosítása, valamint a szokásos kártyaelfogadásra vonatkozó hipotézisek tesztelése. Elemzésünkhöz a NAV által rendelkezésünkre bocsátott, 2016-ra vonatkozó, anonimizált online pénztárgép adatokat használtuk fel. Az adatbázis rendkivül széles körben lefedi a hazai kiskereskedelmet, és a közel 3,8 milliárd adatpont segitségével komplex és robusztus elemzések végezhetók. Az adatokat üzletszinten aggregálva, megyei és hálózati jellemzőkkel, havi szinten vizsgáltuk. A kutatás során robusztus eredmények alapján az üzletméret tekinthető a kártyaelfogadási hajlandóság legfontosabb magyarázó változójának, a kapcsolat azonban nem lineáris. A kis- és nagy méretű üzleteknél a méret marginális hatása elenyésző, a közepes üzleteknél azonban erős pozitiv kapcsolat mutatható ki. Az elemzésünkben vizsgáltuk a vásárlóközönség és a bolt egyéb jellemzőinek hatását is, amelyek közül számos statisztikailag szignifikánsnak bizonyult, ám valójában ezek is csak elenyésző mértékben befolyásolják a kártyaelfogadást. A szubjektiv változók közül a tulajdonosi kör közelitő változójaként használt vasárnapi nyitva tartás azonban jelentős mértékben csökkenti a kártyaelfogadási hajlandóságot.

Journal of Economic Literature (JEL) kódok: C44, G20, D22

Kulcsszavak: pénzforgalom, kártyaelfogadás, fizetési módok, logisztikus regresszió

\section{Célkitűzés}

A tanulmány célja a kiskereskedelmi üzletek fizetésikártya-elfogadási döntésénél fontos szempontok feltárása és azok egyedi hatásainak pontos becslése. A széles üzletkörből adódóan jelenleg még nem készült olyan elemzés, amely a kiskereskedelmi szektor teljes egészén vizsgálta a kártyaelfogadási döntések alapjait. Mivel

\footnotetext{
* Jelen cikk a szerző nézeteit tartalmazza, és nem feltétlenül tükrözi a Magyar Nemzeti Bank hivatalos álláspontját.
}

Ilyés Tamás a Magyar Nemzeti Bank közgazdasági elemzője. E-mail: ilyest@mnb.hu Varga Lóránt a Magyar Nemzeti Bank föosztályvezetője. E-mail: vargalor@mnb.hu

A magyar nyelvű kézirat első változata 2017. június 28-án érkezett szerkesztőségünkbe.

DOI: http://doi.org/10.25201/HSZ.17.1.83109 
sem a pénzforgalmi szolgáltatók, sem a kártyatársaságok nincsenek birtokában egy, a fizetési kártyát el nem fogadó üzleteket is lefedő adatbázisnak, ezért a korábbi hasonló elemzések kérdőíves felmérésre alapultak. A Nemzeti Adó- és Vámhivatal által rendelkezésünkre bocsátott magyar online pénztárgép adatbázis viszont lehetővé teszi a teljes kiskereskedelmi üzletkör vizsgálatát a fizetési kártya elfogadásának szempontjából. A minta méretének köszönhetően szǔk szegmenseket és nagyon kismértékű hatásokat is megbízhatóan ki tudunk mutatni. Fő kutatási kérdéseink:

- A nemzetközi tapasztalatok alapján a kártyaelfogadási döntést legnagyobb mértékben a kereskedő éves forgalmának nagysága befolyásolja. A hazai kiskereskedelmi szektor mennyiben felel meg ennek a megfigyelésnek?

- A várható kártyás forgalom nagysága befolyásolta-e a kártyaelfogadási döntést Magyarországon?

- Az üzletek éves forgalmán felüli egyéb tényezők mennyiben járulnak hozzá a kártyaelfogadáshoz?

- Azonos szempontok szerint tudjuk-e megkülönböztetni a kis, közepes és nagy méretű kártyaelfogadó és kártyát nem elfogadó üzleteket?

- Az egyedi és a hálózatokhoz tartozó üzletek jelentősen különböznek-e a kártyaelfogadási hajlandóságukban? A hálózati döntéseknél a hálózat mérete vagy az egyedi üzletméretek befolyásolják nagyobb mértékben az elfogadást?

A tanulmányunkban először bemutatjuk a kártyaelfogadási hajlandóság elemzésének releváns nemzetközi szakirodalmát, valamint az elemzésünk alapjául szolgáló online pénztárgép adatbázist és a rendelkezésre álló adatokat. A használt változók közül több közvetlenül a számlaszintű adatokból lett előállítva, míg másokat proxyként tudunk használni.

A 3. fejezetben definiáljuk az elemzés módszertanát, valamint a vizsgált változókat és a részminták meghatározásának módját. Ezek után a 4. fejezetben részletesen bemutatjuk az elemzés eredményeit, amelyek robusztusságát több megközelítésből is ellenőrizzük.

\section{A szakirodalom feldolgozása}

A fizetésikártya-elfogadás vizsgálata elsősorban elméleti kutatási terület a pénzforgalmon belül. A kutatások fókusza a bankközi jutalék - interchange díj - hatása a kártyaelfogadásra, illetve annak a vizsgálata, hogy milyen módon lehet meghatározni egy egyensúlyi jutalékértéket az oligopolista bankkártyapiacon. Az egyik első ilyen témájú elemzésben Baxter (1983) a bankközi jutalékok mellett érvel. Ezt a modellt Rochet - Tirol (2003) és Wright (2003) is kritizálta, és az az eredeti modellt 
jelentősen továbbfejlesztette, ám a következtetés továbbra is az volt, hogy felárazás nélkül a bankközi jutalék semleges hatással van a piacra. Rochet és Tirole 2007-es cikkében empirikus tesztet alkotott annak meghatározására, hogy az alkalmazott jutalék szintje nagyobb-e az egyensúlyi értéknél. A teszt alapján Magyarországon is készült elemzés (Keszy-Harmath et al. 2012), amelynek eredményei a bankközi jutalékszabályozás indokoltságát jelezték. Az elméleti modellek azonban kevés támpontot adnak a kártyaelfogadás keresztmetszeti megértéséhez, mivel az egyszerúsített keretben a kereskedők többnyire csak egységköltségükben különböznek egymástól.

Az elméleti modellekkel párhuzamosan az empirikus szakirodalom jelentős része is a kártyaelfogadás költségeire fókuszált (Humphrey et al. 2003; Turján et al. 2010). Az empirikus vizsgálatok sorában a mi kutatásunk fóként a kérdőíves felmérések eredményeire épít. Jonker (2011) 1008 fős holland kereskedői felmérés adatain vizsgálta a kártyaelfogadást és a felárazást. Regressziós vizsgálata alapján azt találta, hogy a kereskedő bevétele és az alkalmazottak száma nagyon szignifikáns magyarázó változó, azonban a szubjektív tényezők és a kártyaelfogadás költsége is hatással van a kártyaelfogadásra. Arango és Taylor (2008) a kanadai piacon mérték fel a kártyaelfogadói hajlandóságot a kereskedői percepciókra fókuszálva, míg Polasik és Fiszeder (2014) az online kereskedők fizetési módjának elfogadási döntéseit vizsgálta. Az empirikus kutatások nagyobb része azonban a kártyahasználatra koncentrál, és nem a kínálati oldalra (Bolt 2008, 2010; Borzekowski 2006).

A kutatásunkban a nemzetközi eredmények hazai alkalmazhatóságát ellenőrizzük, elsősorban a kereskedelem méretének - éves bevétel - és az egyéb, szubjektív tényezők hatásainak kimutatására koncentrálva. A kérdőíves felmérésekhez viszonyítva a jelen kutatás a minta méretéből és a felmérés köréből kifolyólag lehetővé teszi számunkra, hogy számos almintán vizsgáljuk a kártyaelfogadást.

\section{Módszertan}

\subsection{Adatforrás: az online pénztárgép adatbázisa}

A Nemzetgazdasági Minisztérium a 2013/48 (XI. 15.) rendelet alapján tette kötelezővé az adóhatósághoz közvetlenül bekötött online kapcsolattal rendelkező pénztárgépek használatát. A pénztárgépek cseréjére fokozatosan került sor 2014 végén, bizonyos feltételek mellett 2015. január 1-ig még volt lehetőség a hagyományos pénztárgépek használatára. Az online pénztárgépek használatára kötelezettek köre jelentősen bővült a rendelet megalkotása óta. A kezdeti kör elsődlegesen a kiskereskedelmi forgalomra terjedt ki, azonban 2017. január 1-jétől a szolgáltató szektor jelentős része is a rendelet hatálya alá került (pl. taxiszolgáltatás, vendéglátóipar, gépjárműjavítás).

Az online pénztárgépek által az adóhatóság tételes adatokkal rendelkezik mindegyik kiadott számláról. Az elemzésünkhöz a számlaszintű aggregált adatok anonimizált 
adatbázisát használtuk fel. A hatályos jogszabályok alapján a kiskereskedelmi üzletek nem kötelesek minden esetben tételes számlát adni termékenként, csak a különböző áfa-kulcsú termékek gyűjtőkategóriáit kell elkülöníteni. Emiatt teljes körű elemzésre nem használható a tételesen bontott adatbázis. Az aggregált adatok - érték, áfa-tartalom, fizetési mód, üzlethely - mellett a számlán szereplő tételek számáról is rendelkezünk adatokról.

Az üzlethely ismertető adatai csak anonimizálva - véletlenszerűen generált azonosítókon keresztül - kerültek feltüntetésre, a fizikai hely esetén csak a megye ismert, a tevékenységgel kapcsolatban pedig csak az elsődleges, négyjegyű TEÁOR'08 ${ }^{1}$-as kód áll rendelkezésre. A TEÁOR-kódot a kereskedők nem kötelesek a fő tevékenységük alapján kérni, így lehetnek eltérések. Bizonyos speciális tevékenységi körök megbízhatóan azonosíthatók, például az üzemanyag-kereskedelem.

Az adatbázis éves jellegéből adódóan a vizsgált kereskedői kör változott az időszak alatt, több üzlet tulajdonosa cserélődött, számos üzlet csak időszakosan üzemelt. Több esetben előfordult a tevékenységi kör cseréje. Ugyancsak komoly probléma, hogy az anonimizálás következtében nincs lehetőség egy üzlet forgalmának hónapok közötti követésére. A lehetséges adathibákkal együtt emiatt az elemzett adatbázison nem minden esetben derül ki, hogy nem az üzlet müködésében, csupán a bejelentett adminisztrációs adatokban volt változás. Így az elemzésekben több üzlet szerepel, mint amennyi online pénztárgép létezik az országban. Emiatt az adatbázis panel-ökonometriai módszerekkel nem vizsgálható.

Ez a probléma havi rendszerességgel fordul elő, egy hónapon belül nagy megbízhatósággal mind az üzletek tényleges száma, mind a hálózatok kapcsolatai azonosíthatók. Az anomáliát azzal korrigáltuk, hogy minden hónap szerint külön generáljuk az összes üzlet adatait. Ekkor minden üzlet átlagosan 12-szer szerepel az adatbázisban. Ez a megközelítés biztosítja, hogy amennyiben a hónapok közötti azonosítás anomáliája függ a bolt méretétől, a végső adatbázisban az arányok nem torzulnak. Ellenkező esetben például, hogyha a nagyobb boltok könnyebben követhetők, míg a kisebbek többször jelennek meg eltérő azonosítóval, a nyers adatbázisban jelentősen több kisebb üzlet szerepelne, mint a valóságban.

A havi bontással előállított adatbázison kétféle módszerrel van lehetőség a regressziós becslések elvégzésére. Az egyik esetben minden hónap szerint külön regressziót becsültünk. Mivel ekkor 12 regresszió készül, a terjedelmi korlátok miatt a végső táblákban csak egy reprezentatív hónap együtthatóit szerepeltettük. A havi modellek között a legtöbb vizsgált változó esetén nincsenek lényegi eltérések, a részletes táblákat a mellékletbe helyeztük. A második lehetőség, hogy a teljes adatbázist egy modell keretein belül becsüljük. Az egyes alminták között csak szintbeli eltérések

\footnotetext{
${ }^{1}$ A magyar TEÁOR 2008 kódok megfelelnek az európai NACE rev. 2 ágazati besorolásoknak.
} 
lesznek, az egyéb magyarázó változók hatását tekintve a marginális hatások megegyeznek. A modellezésben elsősorban az első megközelítést alkalmazzuk, azonban az eredményeket összevetjük a közös mintán becsült egyenletek paramétereivel. Ekkor természetesen az adott magyarázó változók kártyaelfogadásra vonatkozó hatása az éves átlagos hatás lesz.

\subsection{A becslés lépései}

A kutatásunk célkitűzéseit három, logikailag különálló részre bonthatjuk. Első kérdésünk, hogy az egyes magyarázó változóknak mi a marginális hatása a kártyaelfogadás valószínűségére. A második, hogy a döntési modell szignifikánsan eltér-e a különböző méretű üzletek esetén, míg a harmadik kérdés az, hogy hálózati szintű döntés esetén is eltér-e.

Az első esetben az előző fejezetben bemutatott módon kétféle modell becsülhető aszerint, hogy a havi adatokat közösen vagy külön regresszióban szerepeltetjük. Az elemzésünkben bemutatunk egy olyan modellt, amiben csak az éves bevétel és ortogonális polinomjai szerepelnek, valamint egy összetett modellt az összes szignifikáns magyarázó változóval.

A második kérdéshez első lépésben szerepeltettük a fő magyarázó változók és az éves bevétel keresztszorzatait. Második lépésben a mintát megbontottuk három méretkategóriára az éves bevétel alapján (1. melléklet). A vágási pontokat egy egyszerü döntési fa modellel endogén módon határoztuk meg. A legkisebb csoportba azok az üzletek kerültek, amelyek éves forgalma nem éri el a 15 millió forintot. Ezek az üzletek csak egy vagy két ember munkaerőköltségeit képesek kitermelni. Közepes méretű üzleteknek a 15 és 150 millió forint közötti éves bevételú üzleteket tekintjük. A keresztmetszeti adatok alapján ebben a kategóriában a legnagyobb az éves bevétel marginális hatása a kártyaelfogadásra, minden más változatlansága mellett. Az ennél nagyobb üzleteknél a kártyaelfogadás stabilan magas, és a leíró adatok alapján nem függ érdemben az üzlet méretétől.

A hálózati szintű döntések vizsgálatához három alkategóriát különböztettünk meg. Az egyedi üzleteket különválasztottuk. A hálózathoz tartozó - adóazonosítót közösen használó - üzletek között kártyaelfogadás szempontjából hálózati döntésűnek tekintettük azokat, ahol a kártyaelfogadás vagy nem elfogadás az üzletek több mint 95 százalékát érinti. A fennmaradó üzleteknél feltehetően egyedi döntés születik a kártyaelfogadásról attól függetlenül, hogy egy hálózathoz tartoznak. A három alkategóriát egy dummy változóként szerepeltettük a fő regresszióban is, azonban második lépésben megvizsgáltuk, hogy amennyiben a három alkategória szerint külön becsüljük a regressziót, eltérő eredményeket kapunk-e. A hálózati döntés szerint megkülönböztetett alminták esetében az eredményeket torzíthatja, hogy a szelekció endogén módon, a függőváltozótól függően történik. A jelen tanulmánynak nem 
célja ennek a problémának a pontos korrigálása, az eredmények ennek megfelelően kellő óvatossággal kezelendők.

A becsült logit modell azt mutatja, hogy egy adott tulajdonságú üzlet várhatóan kártyát elfogadó vagy nem elfogadó lesz a vizsgált időszakban. A modell dinamikusan, a kártyaelfogadás bevezetését tekintve nem értelmezhető. A kártyaelfogadás időbeli döntésében feltehetően jelentős a tehetetlenség, azaz az előző időszaki döntés fontos magyarázó változó a következő időszakra vonatkozóan. A tanulmányunk nem ezt az időbeli, sztochasztikus folyamatot elemzi, hanem a folyamat által egy adott pillanatban generált elfogadó-nem elfogadó állapotot. A hiányzó változó okozta torzítás esetén az eredmények ilyen értelmezése torzított és hibás lenne. Az eredmények kizárólag a kártyaelfogadó és nem elfogadó üzletek közötti statisztikailag szignifikáns különbségeket mutatják. Ez a megközelítés elsősorban az adatbázis hiányosságaiból következik, másodsorban azonban az eredményeket összehasonlíthatóvá teszi más nemzetközi felméréseken végzett elemzésekkel.

Az elemzésünkben a következő regressziókat elemeztük:

- Csak az éves forgalmat tartalmazó modell

- Összevontan, éves adatokon

- Havi bontásban

- Összes szignifikáns változót tartalmazó modell

- Összevontan, éves adatokon

- Havi bontásban

- Teljes modell az éves bevétellel vett keresztszorzatokkal

- Összevontan, éves adatokon

- Havi bontásban

- Hálózati döntés szerint almintákra bontott modell havi bontásban

- Nem hálózathoz tartozó üzletek

- Hálózathoz tartozó üzletek

• Üzletszintű kártyaelfogadási döntés

- Hálózatszintű kártyaelfogadási döntés

- Éves bevétel szerint almintákra bontott modell havi bontásban

- Kis méretű üzletek

- Közepes méretű üzletek

- Nagy méretű üzletek

A modellek összetettsége és a változók közötti nagymértékű multikollinearitás miatt a közvetlen összehasonlítás bináris függő változó esetén nem egyértelmű. 
Az elemzésünkben két modellt hasonlónak tekintünk, ha a magyarázó ereje és az általa generált klasszifikálás megegyezik a többi részmintán is.

\subsection{Használt változók}

\section{Függő változó}

A kutatási kérdésünknek megfelelően az elsődleges függő változó a kártyaelfogadás. Egy kereskedőt vagy üzletet kártyaelfogadónak tekintünk, ha az adatbázisban köthető hozzá fizetési kártyás tranzakció. Mivel a fizetési információ a pénztárgépen sok esetben manuálisan kerül rögzítésre, ezért előfordulhatnak hibás tranzakciók. Az elemzéseink során az alsó hibahatárt 0,5 százaléknak választottuk.

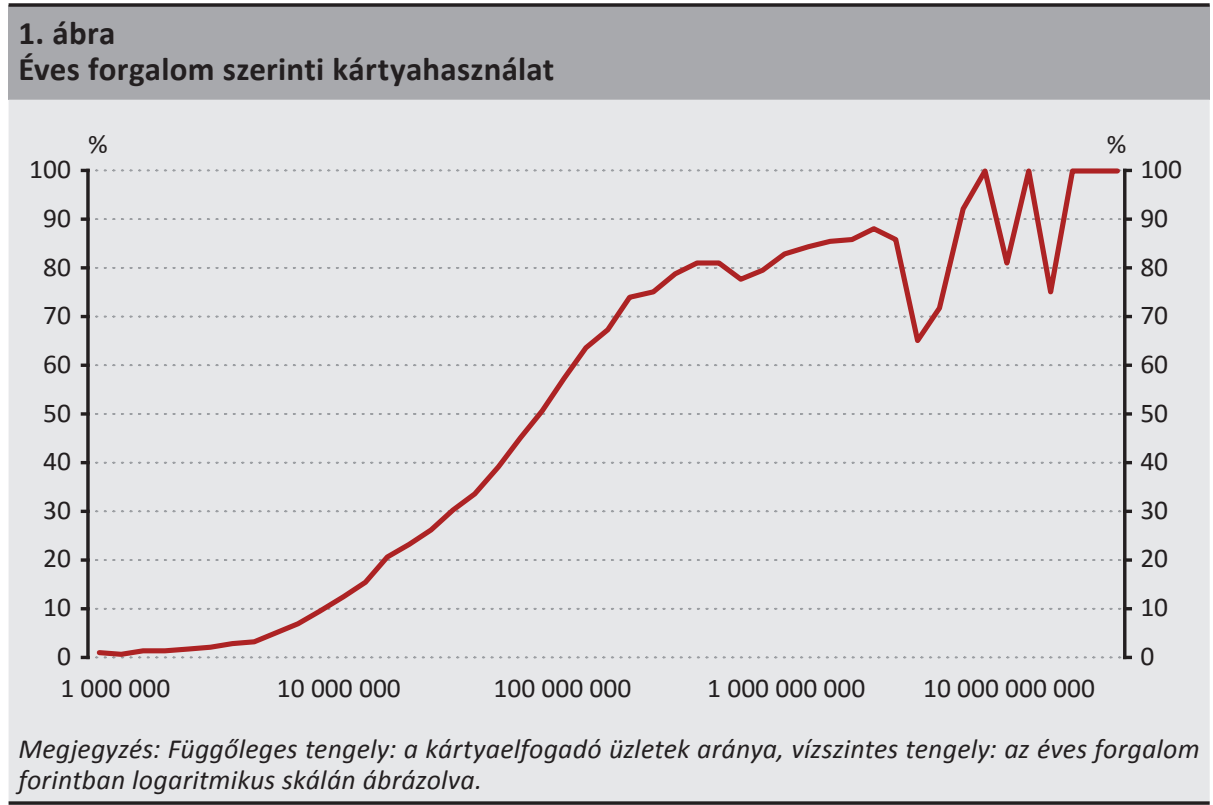

\section{Üzletméret}

A legfontosabb és legmeghatározóbb használt magyarázó változó az elemzésünkben az üzlet mérete. Az üzletről külső információkkal nem rendelkezünk, ezért az éves forgalmat a hozzá köthető számlák összegéből állítjuk elő. Ez a nyers adatsor jó matematikai jellemzőkkel - lognormális-exponenciális eloszlás - rendelkezik, azonban a fent említett azonosítási problémák miatt torzítást okozhat. Mivel bizonyos esetekben egy üzlet adatváltozás miatt többször jelenik meg, több kisebb forgalmú üzletként szerepelne az adatbázisban. Emiatt az évesített forgalmat használjuk, amit a tényleges forgalom és a múködési napok alapján számolunk. A vizsgált időszak - 2016 - magában foglalja a vasárnapi zárva tartást és a rendelet eltörlése utáni időszakot - az eltörlésről szóló rendelkezés 2016. április 15-én került kihirdetésre. 
Az üzletméret és a kártyaelfogadás kapcsolata erős, azonban nem lineáris (lásd 1. ábra), ezért összetett függvényformákra van szükség a jó magyarázó erő érdekében. A modellekben szerepeltetjük az üzletméret logaritmusának ortogonális polinomjait. Az üzletméret szerint feldarabolt modellek esetében maga a mintaszelekció is tovább növeli a függvényforma komplexitását.

A magyarázó változók között felmerülhet a kártyaelfogadás, valamint a készpénzkezelés átlagos költsége. A kártyaelfogadás alapjaiban egy fix - a terminál építése és üzemeltetése - és változó költségből, főként kereskedői jutalékból áll. Az intuitív megközelítés alapján, amennyiben a bolt éves forgalma elég nagy, a kártyaelfogadás alacsonyabb egységköltséget ér el, mint a készpénz. A Magyar Nemzeti Bank felmérései alapján a rendkívül intenzív hazai készpénzforgalom miatt a készpénz költségelőnye még a legnagyobb boltoknál is megmarad, ezért ez nem lehet közvetlen döntési szempont.

\section{Értékkategóriák}

Az adatbázis keresztmetszeti elemzése alapján megállapítható, hogy a fizetés értékétől nagymértékben függ a kártyahasználati hajlandóság. Feltételezhetően emiatt egy ugyanakkora éves forgalommal rendelkező üzletben magasabb lesz a tényleges használat, ha a megfelelő értékkategóriába tartozik a tranzakció többsége, szemben azokkal az üzletekkel, ahol többségében nagyon kicsi vagy nagyon nagy értékű tranzakciók adják a forgalom jelentős részét. A forgalmat ezért az 1. táblázatban feltüntetett értékkategóriák szerint bontottuk fel.

\begin{tabular}{c|c}
$\begin{array}{l}\text { 1. táblázat } \\
\text { Értékkategóriák szerinti kártyahasználat } \\
\text { Értékkategória }\end{array}$ & Átlagos kártyahasználat 2016-ban \\
\hline 1000 HUF alatti tranzakciók & $5,0 \%$ \\
\hline $1000-5000$ HUF közötti tranzakciók & $15,1 \%$ \\
\hline $5000-10000$ HUF közötti tranzakciók & $27,7 \%$ \\
\hline $10000-20000$ HUF közötti tranzakciók & $37,0 \%$ \\
\hline 20000 HUF feletti tranzakciók & $29,6 \%$ \\
\hline
\end{tabular}

A forgalom szerkezeténél külön vizsgálható az egyes kategóriák abszolút forgalma és az arányuk. Arányok esetén a referenciakategória minden esetben a legnagyobb értékkategória. A kapcsolat jellegéből adódóan a magyarázó változók számának korlátozása miatt a végső modellekben a forgalom logaritmusa szerepel, valamint annak négyzete. 


\section{Az üzletek időbeli jellemzői}

A számlákon szereplő dátumok alapján nemcsak az üzletek évesített forgalma, hanem annak havi, heti eloszlása is meghatározható. Ezek alapján az elemzés során vizsgáltuk a heti forgalmi szerkezet hatását is a kártyaelfogadásra. A vizsgált év jelentős részében a kiskereskedelmi szektorban érvényben volt a vasárnapi zárva tartást előiró rendelet, amely alól a legjelentősebb kivételeket a tulajdonos által üzemeltetett üzletek képezték. Így a vasárnapi nyitva tartás proxy változóként használható a tulajdonosra vonatkozóan. A megfeleltethetőség nem tökéletes, így a változó csak a TEÁOR-változóval együtt szerepel a modellekben. lly módon az egyes szektorális kivételek hatásait el tudjuk különíteni a tulajdonos jellemzőitől.

Az elemzés során a hétfői és a keddi zárva tartás bizonyult szignifikáns magyarázó erővel rendelkező változónak, így a többi modellben kontrollváltozóként ezek szerepelnek. Ezek a tulajdonságok olyan speciális boltokra utalnak - például múzeum boltja, mintaáru-kereskedés stb. - ahol az üzlet nem tekinthető önálló pénzügyi egységnek.

\section{Hálózati jellemzők}

A kiskereskedelmi szektor jelentős része hálózati formában múködik, azaz egy jogi személy üzemeltet számos üzletet. A hálózati jelleg a hipotéziseink szerint kétféle formában hat a kártyaelfogadási döntésekre. Azokban a hálózatokban, ahol a hálózat minden tagja egy kategóriába sorolható - elfogad vagy nem fogad el - feltételezhetően hálózati szintű döntés született a kártyaelfogadásról, így maga a döntési helyzet eltérhet az egyedi üzletekétől. Ezzel szemben az olyan hálózatokban, ahol a megfigyelések szerint egyedi, üzletszintű döntés a kártyaelfogadás, az üzlet egyedi jellemzői határozzák azt meg. Emiatt a modellezés során vizsgáltuk annak a hatását, amikor a mintát a típusok szerint három részre bontjuk - egyedi bolt, egyedi döntés és hálózati döntés -, valamint a hálózati boltok esetén a hálózat teljes forgalma és üzletszáma is szerepel. A keresztmetszeti elemzések alapján a kapcsolat nem lineáris, emiatt a négyzetes tagokat is szerepeltetjük a regressziókban.

\section{Tevékenység}

A NAV adatbázisa tartalmazza az üzletek elsődleges tevékenységi körének TEÁOR-azonosítóját négy számjegy bontásban. A minta jellegéből adódóan az üzletek közel háromnegyede a szúken értelmezett kiskereskedelmi szektorba tartozik. A részletes bontás becslése problémás, a modellezés során több esetben nem is végezhető el teljesen - példaként egy bizonyos altevékenységhez csak elfogadó vagy nem elfogadó üzletek tartoznak - vagy a dummy változók nagy száma okoz problémát a modell becslésénél. Emiatt a modellek többségében csak az azonosító első három számjegyét használjuk fel. Ezen szabály alól kivételt képeznek a döntési fa és döntési erdő modellek, ahol ez a jelenség nem okoz technikai problémát. 


\section{Megyekód}

Az üzlethelyek anonimitásának biztosítása érdekében nem szerepel a magyarázó változók között a pontos fizikai hely, csak a megye azonosítója. Ez sajnos jelentős mértékben csökkenti az eltérő vásárlóközönséggel rendelkező üzletek vizsgálatát, mivel csak 21 különböző típust tudunk megkülönböztetni. A 21. megyekód a stabil hellyel nem rendelkező mozgóboltokat jelöli. A vásárlókörre vonatkozó információk nem szerepelnek a modellekben, hanem csak a megyekódok és a főváros dummy változói. Második lépésben a dummy változók együtthatóit magyarázzuk az adott megye aggregált adataival.

\section{Tételszám}

A számlákhoz kapcsolódóan az adatbázisban szerepel a vásárolt termékek száma. Ennek segítségével az elemzéseinkben felhasználtuk az üzlet teljes tételszámát egy más megközelítésű méretváltozóként, valamint az átlagos és maximális tételszámot. Az átlagos és maximális tételszám feltehetően erősen korrelál a fizetési idővel, így ennek a proxy változójaként használjuk. Kontrollváltozóként több esetben használtuk az átlagos fizetési értéket, azonban ez a változó nagyon erősen összefügg az érték szerint megbontott forgalommal és a sávok arányaival.

A fő magyarázó változók legfontosabb statisztikai jellemzői a 2. mellékletben találhatók.

\section{Eredmények}

A célkitǔzésben bemutatott módon az első kérdésünk, hogy az éves forgalom milyen mértékben magyarázza önmagában a kártyaelfogadást Magyarországon. A nemzetközi szakirodalom alapján az üzlet forgalmának mérete a legfontosabb magyarázó változó a kártyaelfogadási döntéseknél. Ezután bemutatjuk, hogy az értékkategóriák szerinti forgalom milyen mértékben befolyásolja a teljes forgalom hatását. Második lépésben az egyéb faktorok hatását elemezzük - ágazat, földrajzi hely - majd a méret és a hálózati döntés szerint feldarabolt mintákon becsült modellek egyezőségét.

\subsection{Méretváltozók hatása}

Az eredmények alapján (3. melléklet) megállapítható, hogy csak az éves forgalom alapján becsülve is közepesen jól elkülöníthetők egymástól a kártyaelfogadó és nem elfogadó üzletek. Azaz a kártyaelfogadás bevezetésénél a legfontosabb szempont az üzlet éves forgalma. A magas fokú polinomok nagy szignifikanciája arra utal, hogy a logisztikus függvényforma alapvetően nem képes jól magyarázni a folyamatokat. Ennek legfőbb oka, hogy a méret hatása nem lineáris (2. ábra). A 150 milliós éves forgalom feletti üzleteknél a méret marginális hatása jelentősen csökken. Ez az eredmény visszaadja az adatbázis keresztmetszeti elemzésénél megfigyelt jelenséget. 


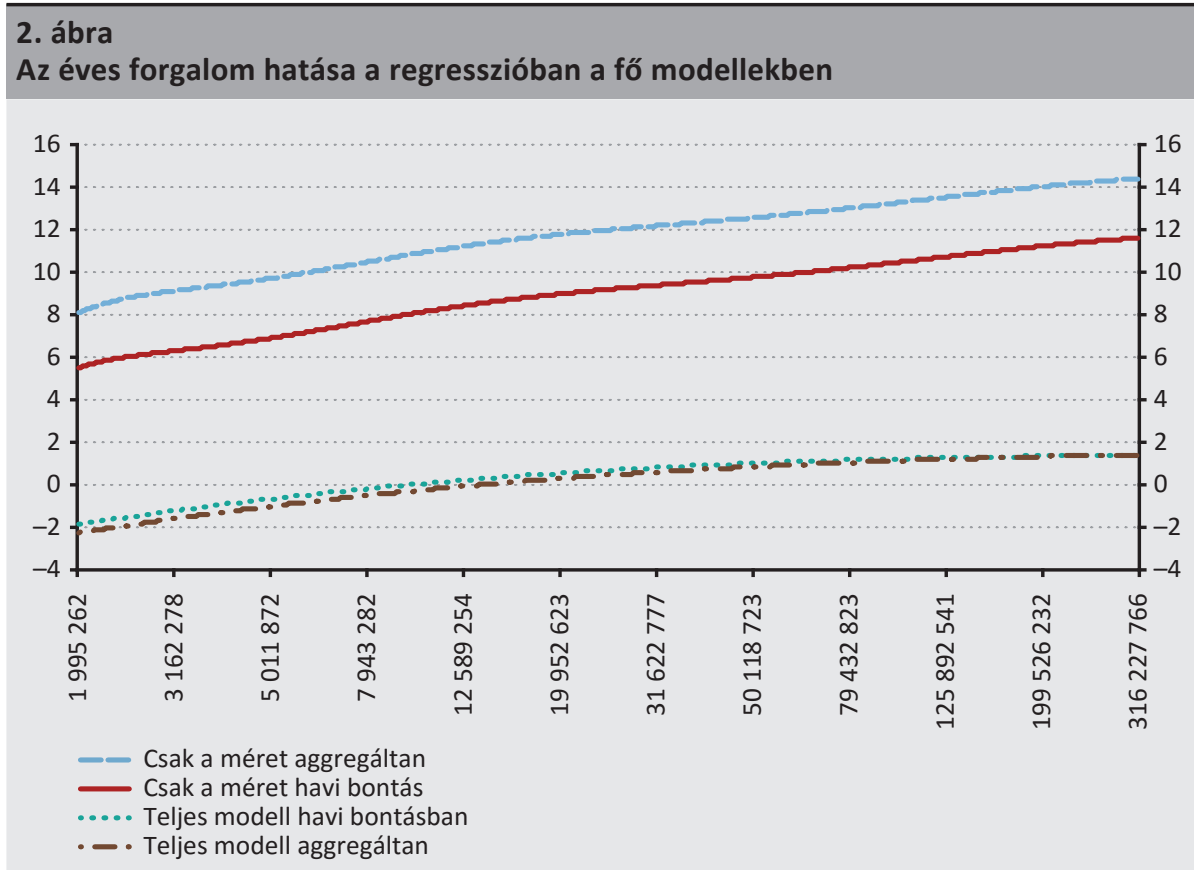

Megjegyzés: A logisztikus regressziók esetében az együtthatók hatása közvetlenül kétféle módon értelmezhető, az egyedi hatás a magyarázó változók skáláján a logisztikus transzformáció előtt, valamint a függő változó skáláján odds-ráta szorzóként. A polinomiális függvényformák könnyebb értelmezhetősége érdekében a cikkben az első változat szerint mutatjuk be az eredményeket, így nagyságrendileg összehasonlíthatók a különböző változók szerint. Függőleges tengely: a számolt hatás a magyarázó változók skáláján számolva, vízszintes tengely: az éves forgalom logaritmus skálán ábrázolva.

Az éves forgalom hatását az értékkategóriák szerint megbontott forgalom lényegileg nem módosítja, a modell magyarázó ereje jelentősen nem javul (4. melléklet). Ezen túl a különböző kategóriák eltérő mértékben hatottak a kártyaelfogadásra. Azok a boltok, ahol elfogadnak kártyát, nagyobb valószínúséggel rendelkeznek gyakran kártyával fizetett tranzakciókkal. A 10 és 20 ezer forint közötti tranzakciók hatása a legerősebb, míg a kártyával relatíve kis arányban fizetett tranzakciók kis mértékben még rontják is a kártyaelfogadás esélyét (3. ábra). A teljes hatás azonban nagyságrenddel kisebb, mint az éves forgalom hatása. Ezek alapján az a megállapítás tehető, hogy bár az értékkategóriák szerinti megbontás statisztikai szempontból szignifikáns, a hatásuk nem jelentős, a teljes éves forgalom önmagában is jól magyarázza a kártyaelfogadást Magyarországon. 


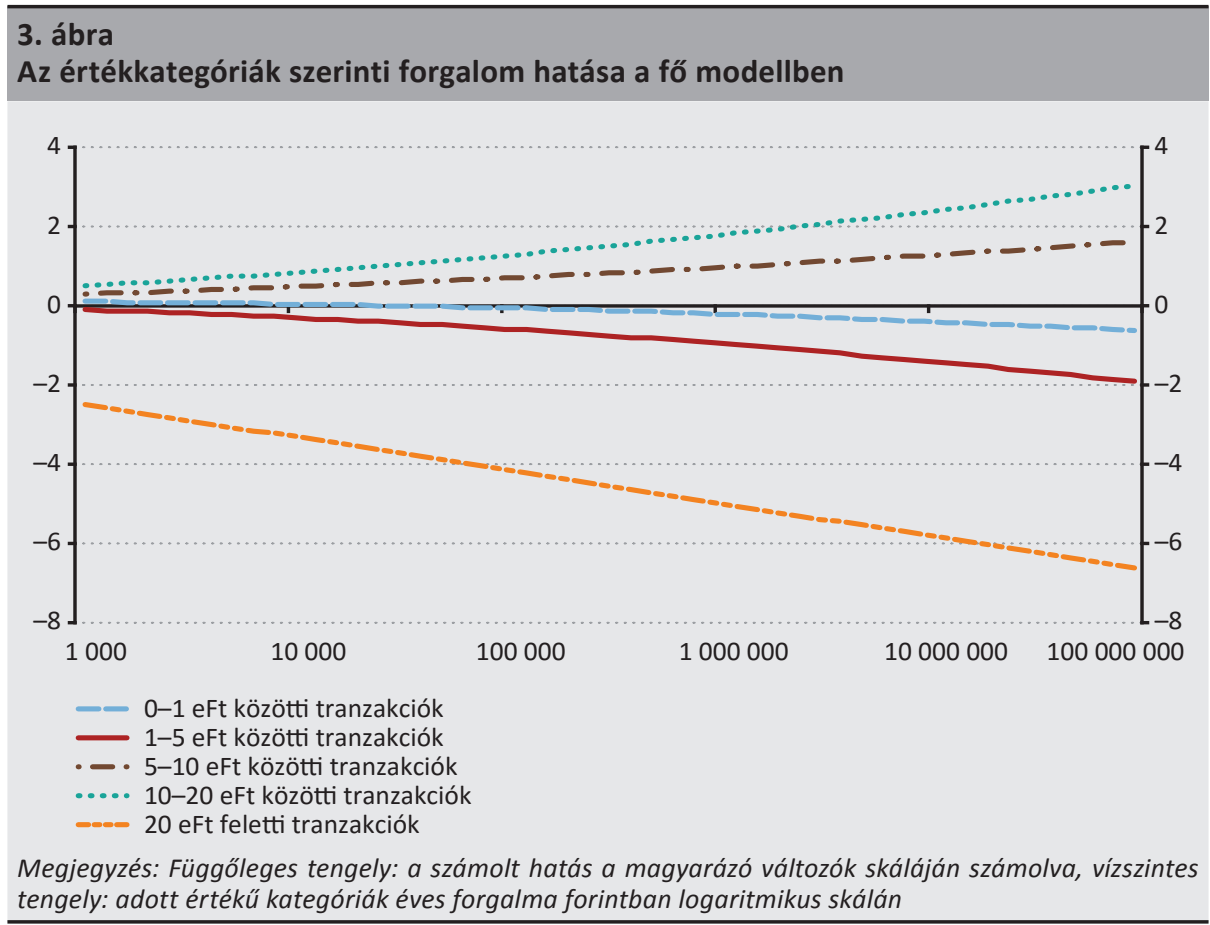

\subsection{Egyéb faktorok hatása}

A logisztikus regressziót számos egyéb magyarázó változóval bővítettük, a modell magyarázó ereje azonban csak kismértékben változik ezek hatására. A nagy mintaelemszámnak köszönhetően az elemzésünkben tudunk azonosítani kis hatásokat is, amelyek statisztikailag szignifikánsak ugyan, de nagymértékben nem befolyásolják a kártyaelfogadási döntést. A dummy változók közül három emelhető ki, amely relatíve nagyobb hatással bír a függő változóra. A vasárnapi nyitva tartás jelentősen rontja a kártyaelfogadás valószínűségét, míg a részletezett számla adása jelentősen növeli. A többi változó az értékkategóriákhoz hasonlóan kis hatással rendelkezik, és marginális értékük megfelel a vártaknak. A hálózat mérete és a boltok száma mind növeli a kártyaelfogadást, de csökkenő mértékben. Ezzel szemben a hálózati döntésü üzletek dummy változója a legalacsonyabb értékü. Ebből arra következtethetünk, hogy Magyarországon minden más hatásra kontrollálva - elsősorban a méret jellegü változók hatását kiszűrve - a hálózati döntésű üzletek kisebb valószínűséggel váltak kártyaelfogadóvá, mint a független üzletek. Az adatbázisban a hálózati döntésű üzleteknél magas a kártyaelfogadás, azonban esetükben a méret hatása erőteljesebb. Az eredmények úgy értelmezhetők, hogy a kártyaelfogadás elutasítása mellett döntő hálózatok összességében a méretükhöz mérten kisebb valószínűséggel fogadnak el kártyát. Összességében megállapítható, hogy az egyéb faktorok hatása csekély, az éves forgalom magyarázó erejével össze nem mérhető. 
Az elemzéseinkhez csak az üzlethelyek megyekódjai álltak rendelkezésre, így a kevés megfigyelés miatt a megyékhez kapcsolódó információkat nem szerepeltettük közvetlenül a modellben. Egy második lépésben viszont a megyékhez tartozó dummy változók együtthatóját vizsgáltuk abból a szempontból, hogy az milyen mértékben magyarázható a rendelkezésre álló megyei szintű szociodemográfiai statisztikákkal. A megyekódok száma a fővárossal összesen 20, így az alacsony mintaelemszám miatt regressziót nem becsültünk, csak lineáris korrelációt vizsgáltunk.

A vizsgált változók közül a munkaképes korú lakosság aránya, a községek száma és az egy bevásárlóközpontra jutó lakosok száma mutat közepesen erős kapcsolatot. A várakozásokkal ellentétben a fejlettségi és jövedelmi változók semmilyen szinten nem bizonyultak szignifikánsnak. A korreláció a főváros kiemelkedő, outlier adatpontja elhagyása esetén sem javul. Ezek alapján az a megállapítás tehető, hogy a rendelkezésre álló adatok alapján a vásárlóközönség megyei szintű összetétele és a kártyaelfogadás között nem mutatható ki kapcsolat. Az együtthatók érdemben nem változnak abban az esetben sem, ha csak a független döntésű üzletek almintáján végezzük el a becslést. Azonban a fő szociodemográfiai változókat tekintve jelentős szóródás figyelhető meg megyén belül is, így a kimutatható kapcsolat hiánya eredhet az aggregálás szintjéből. Amennyiben valamilyen kapcsolat áll fenn, akkor ahhoz mélyebb szinten bontott, feltehetően településszintű adatokra van szükség.

A változók közötti magas multikollinearitás bizonytalanná teszi a paraméterbecsléseket, emiatt többféle kombinációban vizsgáltuk a változócsoportok szignifikanciáját és előjelét. A fő problémát az okozza, hogy a legtöbb konstruált változó erős korrelációt mutat az üzletmérettel, egyes esetekben ez definíciós összefüggés - például az értékkategóriák szerinti forgalom - másoknál viszont tapasztalati összefüggés. Ennek kiküszöbölésére lefuttattuk a regressziókat méretváltozók nélkül is, és megvizsgáltuk, hogy mennyi a többi változó magyarázó ereje. Az eredmények azt igazolják, hogy a tételszám és az értékkategóriák aránya erősen korrelál a mérettel, és a szúkített modellben átveszik szerepét. A modell magyarázó ereje nagymértékben csökken a méretváltozók közvetlen szerepeltetése nélkül. Ez arra utal, hogy a magyarázó erő jelentős részét közvetlenül nem képesek átvenni a fennmaradó változók.

\subsection{Az almintákra bontás hatása}

A regresszióban szerepeltettük az egyéb faktorok és az éves forgalom keresztszorzatait is, amelyek kivétel nélkül szignifikánsak lettek. Ezek alapján a különböző méretű boltoknál a marginális hatás jelentősen eltér. A hálózati döntés szerint képzett dummyk is erősen szignifikánsak a modellben. A kutatási kérdésünk további vizsgálatához ezért az előző fejezetben leírt módon feldaraboltuk a mintát kis, közepes és nagy üzletekre, és újrabecsültük a regressziókat (4. ábra és 5. melléklet).

A három becsült regresszió a saját almintán közepesen jól teljesít, azonban főként a nagy méretű üzleteknél a magyarázó erő jelentősen romlik. Azaz a kis és közepes 
méretű üzleteken becsült regresszió nem alkalmazható a nagy üzleteknél. A paraméterek vizsgálata alapján megállapítható, hogy főként az értékkategóriák szerinti hatás különbözik jelentős mértékben a méret szerint. Míg a kis és közepes üzleteknél az értékkategóriák szerint bontott forgalom az előző fejezetben leírtak szerint csak kis hatással rendelkezik, a nagy üzleteknél jelentősen javítja a modell pontosságát. Összefoglalóan megállapítható, hogy méret szerinti bontásban a legnagyobb kategóriába tartozó üzleteket egyértelműen külön kell kezelni. A nagy forgalmú üzleteknél a kártyaelfogadás jól magyarázható a megfigyelt tényezőkkel.

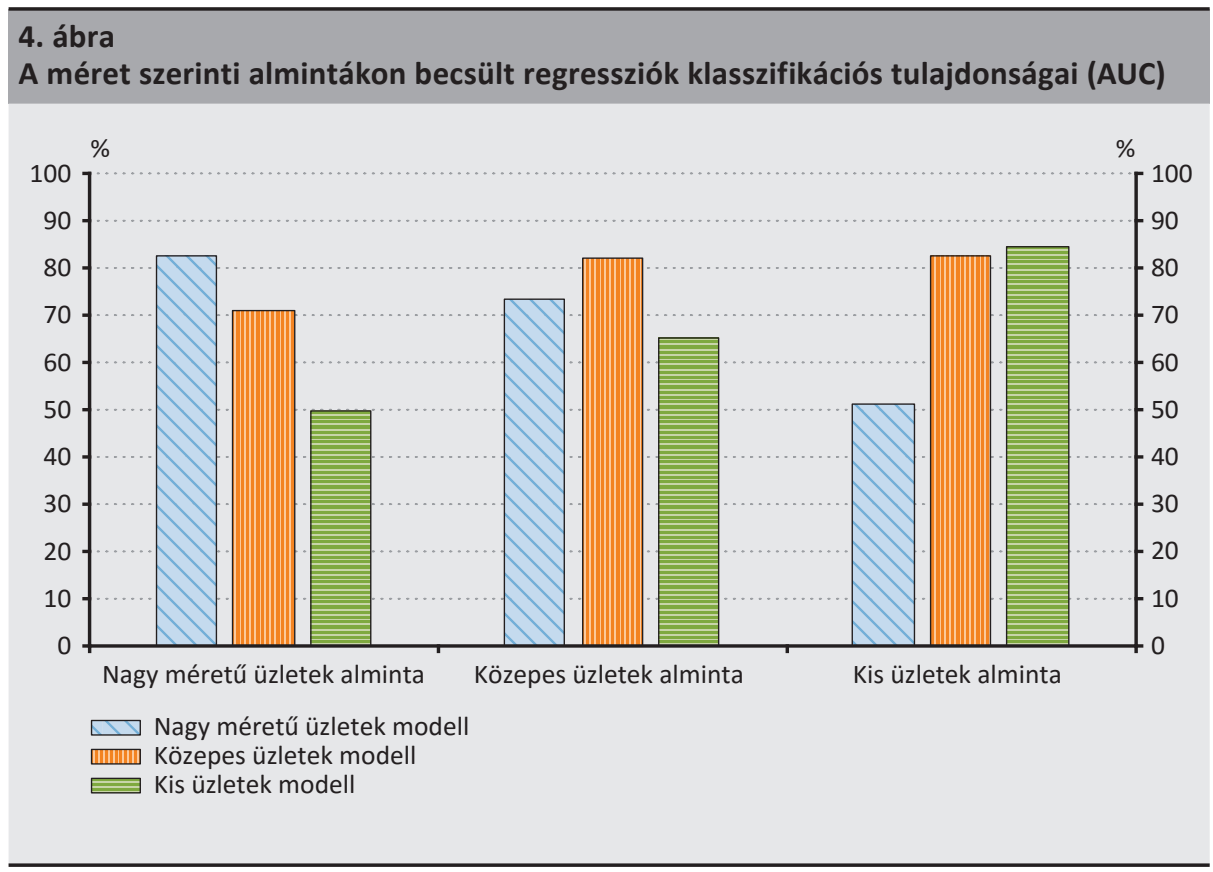

A minta és a becsült modellek feldarabolását elvégezhetjük a hálózati döntések típusa szerint is (5. ábra és 5. melléklet). Ezen csoportosítás szerint jelentősen nagyobb különbségek figyelhetők meg a modellek magyarázó erejében. Egyértelműen megállapítható, hogy a hálózatba nem tartozó üzleteknél más szempontok szerint választhatók el a kártyaelfogadó és nem elfogadó üzletek, mint a hálózathoz tartozó üzletekben. A modellek alapján megállapítható, hogy a hálózat mérete jelentős mértékben magyarázza a kártyaelfogadást a megfelelő üzletekben, és nem kezelhetjük egyedi üzletekként őket. 


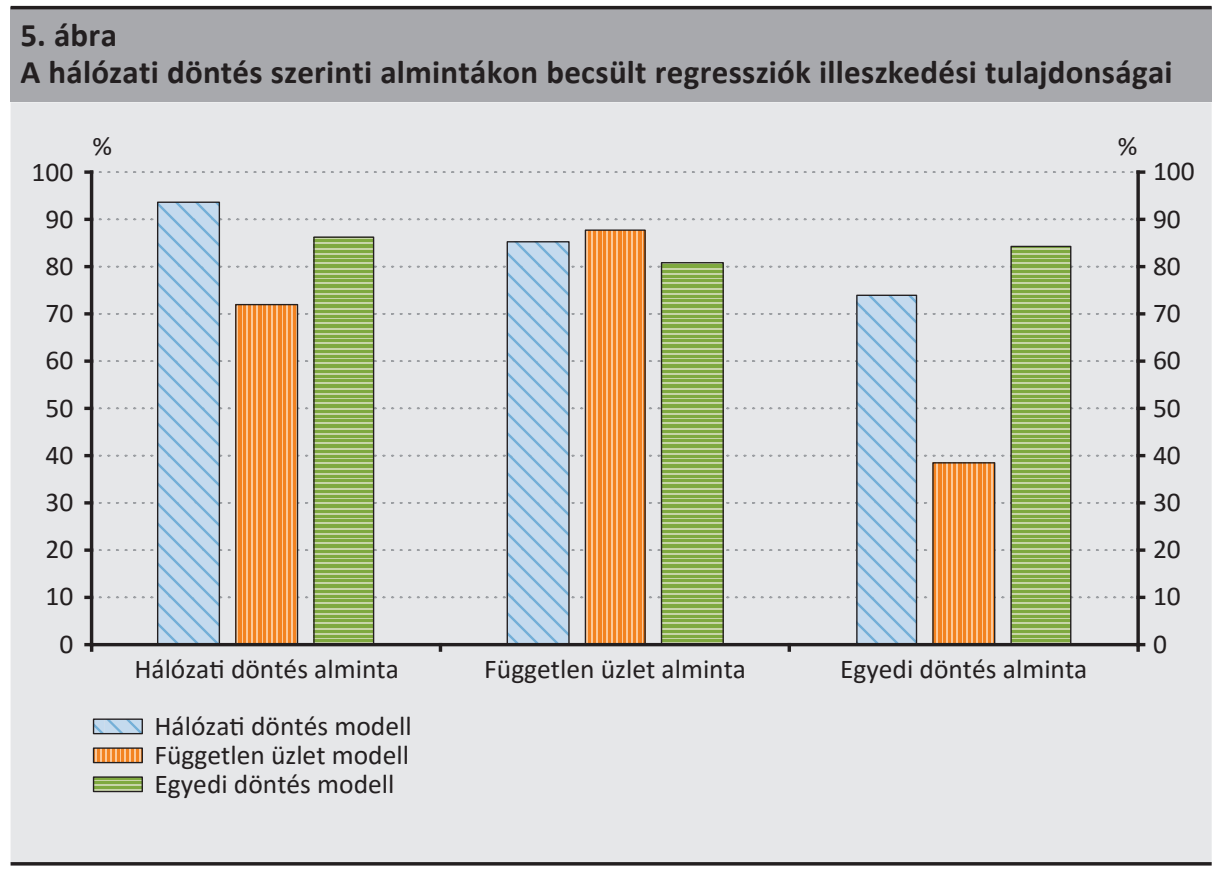

\subsection{A magyarázó változók hatásának szimulálása}

A logisztikus regresszió paraméterei közvetlenül nagyságrendileg nem értelmezhetők. Ezért a különböző változók hatását szimuláció segítségével elemeztük. A szimuláció futtatásához az előző pont modellje alapján új becsléseket készítettünk úgy, hogy minden változó értétét egyesével megnöveltük 10 százalékkal a többi változatlansága mellett. A dummy változóknál a magasabb értékre cseréltük a változókat, a megye változójánál minden üzletnél Budapestet szerepeltettük. A 6. ábra mutatja az egyes szimulációk eredményeit. A legnagyobb hatása a forgalomnak van közvetlenül, és közvetve a keresztszorzatokon keresztül. A hálózati forgalomnak hasonló nagyságrendű az együtthatója. A dummy változók közül a vasárnapi nyitva tartás és hétfői zárva tartás jelentős mértékben csökkenti a kártyaelfogadás valószínűségét, míg a megyei változók közül Budapest hatása kiemelkedő. 


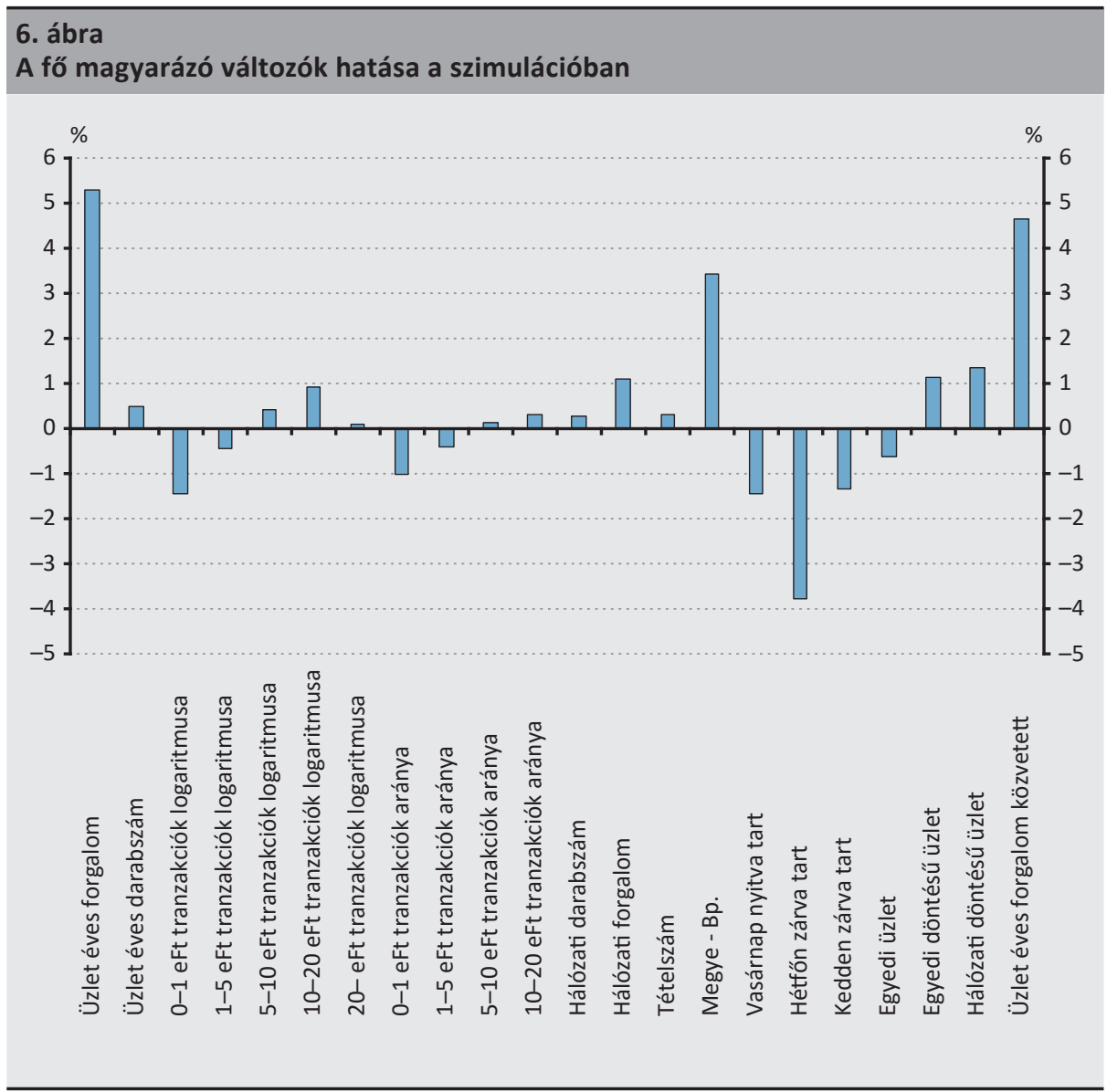

\section{5. Összefoglalás}

A tanulmányunkban a számlaszintű, részletes online pénztárgép adatbázis alapján vizsgáltuk a fizetésikártya-elfogadást a hazai kiskereskedelmi szektorban. A kutatásunk fő célja az elsődleges magyarázó változók azonosítása volt, valamint a szokásos kártyaelfogadásra vonatkozó hipotézisek tesztelése.

Az elemzésünkhöz a NAV által rendelkezésünkre bocsátott, 2016-ra vonatkozó anonimizált adatokat használtuk fel. Az adatbázis rendkívül széles körben lefedi a hazai kiskereskedelmet és a közel 3,8 milliárd adatpont segítségével komplex és robusztus elemzések végezhetők. Az adatokat üzletszinten aggregálva, megyei és hálózati jellemzőkkel, havi szinten vizsgáltuk. 
Az elemzésünk alapján megállapítható, hogy a nemzetközi tapasztalatokkal öszszhangban a fizetési kártya elfogadását legnagyobb mértékben az üzlet mérete magyarázza, amit az esetünkben az éves bevétellel közelítettünk. A bevétel legnagyobb mértékben a közepes méretü üzleteknél hat az elfogadásra, a kis és a nagy méretűeknél a marginális hatás jelentősen alacsonyabb. Az eredmények alapján megállapítható, hogy a logisztikus függvényforma nem feltétlenül jellemzi megfelelöen a méret és az elfogadás közötti kapcsolatot, összetettebb polinomiális függvényformára van szükség a kapcsolat megfelelö leirrásához.

A bevétel mértékén felül szerkezete is befolyásolja az elfogadást, azonban kisebb mértékben. Amennyiben egy üzlet forgalma nagyobb részben olyan értékú tranzakciókból áll, amelyeknél magasabb a várható kártyahasználat aránya, akkor nagyobb valószínúséggel fogad el fizetési kártyát. Az értékszerkezet hatása kimondottan a közepes és nagy méretü üzletek körében szignifikáns, a hatás mértékét tekintve a legnagyobb üzletkategóriában kiemelkedő mértékű.

A bolt nyitva tartása és közvetve a tulajdonosi kör hasonlóan nagymértékben befolyásolja a kártyaelfogadást, az üzlet tulajdonosa által vezetett boltoknál ez szignifikánsan alacsonyabb. A vásárlóközönség jövedelmi helyzete az eredményeink szerint nincs szignifikáns kapcsolatban az elfogadással, azonban a kérdés alapos vizsgálata megyei szintnél részletesebb adatokat igényelne.

A kiskereskedelem hálózati típus és méret szerinti csoportosítása szignifikáns mértékben nem javítja a modellek előrejelző képességét, azonban kismértékben hat az egyéb, szignifikáns változók körére több almintán is. Ezek alapján az a megállapítás tehető, hogy a nem hálózatba tartozó üzletek és a legnagyobb méretkategóriába eső boltok térnek el jelentös mértékben a kártyaelfogadás szempontjából és mindenképpen külön vizsgálandók.

\section{Felhasznált irodalom}

Arango, C. - Taylor, V. (2008): Merchant acceptance, costs, and perceptions of retail payments: a Canadian survey. Bank of Canada Discussion Paper, No. 2008-12.

Baxter, W.F. (1983): Bank Interchange of Transactional Paper: Legal and Economic Perspectives. Journal of Law and Economics, 26(3): 541-588. https://doi.org/10.1086/467049

Bolt, W. (2008): Consumer Choice and Merchant Acceptance of Payment Media. DNB Working Papers No. 197, December, De Nederlandsche Bank.

Bolt, W. - Jonker, N. - van Renselaar, C. (2010): Incentives at the counter: An empirical analysis of surcharging card payments and payment behaviour in the Netherlands. Journal of Banking \& Finance 34: 1738-1744. https://doi.org/10.1016/j.jbankfin.2009.09.008 
Borzekowski, R. - Kiser, E.K. - Ahmed, S. (2006): Consumers' Use of Debit Cards: Patterns, Preferences, and Price Response. Finance and Economics Discussion Series Divisions of Research \& Statistics and Monetary Affairs Federal Reserve Board, Washington, D.C. 200616.

Humphrey, D. - Willesson, M. - Lindblom, T. - Bergendahl, G. (2003): What Does it Cost to Make a Payment? Review of Network Economics (2): 159-74. https://doi.org/10.2202/1446-9022.1024

Jonker, N. (2011): Card acceptance and surcharging: the role of costs and competition. DNB Working Paper No. 300, May, De Nederlandsche Bank.

Keszy-Harmath, É. - Kóczán, G. - Kováts, S. - Martinovic, B. - Takács, K. (2012): The role of the interchange fee in card payment systems. MNB Occasional Papers 96.

Polasik, M. - Fiszeder, P. (2014): Factors determining the acceptance of payment methods by online shops in Poland. https://www.researchgate.net/publication/228867191_The_ acceptance_of_payment_methods_on_the_Polish_e-commerce_market. Letöltve: 2017. május 23.

Rochet, J.-Ch. - Tirole, J. (2003): An Economic Analysis of the Determination of Interchange Fees in Payment Card Systems. Review of Network Economics, 2(2): 69-79. https://doi.org/10.2202/1446-9022.1019

Rochet, J.-Ch. - Tirole, J. (2007): Must-take cards and the Tourist Test. DNB Working Paper, no. 127, January, De Nederlandsche Bank.

Turján, A. - Divéki, É. - Keszy-Harmath, É. - Kóczán, G. - Takács, K. (2011): Nothing is free A survey of the social cost of the main payment instruments in Hungary. MNB Occasional Papers, vol. 93.

Wright, J. (2003): Optimal Card Payment Systems. European Economic Review, 47(4): 587-612. https://doi.org/10.1016/S0014-2921(02)00305-7 


\section{Melléklet}

\section{1. melléklet: A részminták átlagos elemszámai}

\begin{tabular}{l|c|l|c}
\hline Méret szerinti alminták & & Típus szerinti alminták & \\
\hline Kis méretű üzletek & 73247 & Hálózati döntésű üzletek & 61996 \\
\hline Közepes méretű üzletek & 91676 & Egyedi üzletek & 81411 \\
\hline Nagy méretű üzletek & 21153 & Egyedi döntésű üzletek & 42670 \\
\hline Összesen & 186076 & Összesen & 186076 \\
\hline
\end{tabular}

2. melléklet: Az adatbázis változóinak fő jellemzői

\begin{tabular}{|c|c|c|c|c|}
\hline & Átlag & $\begin{array}{c}\text { Standard } \\
\text { hiba }\end{array}$ & Minimum & Maximum \\
\hline Éves bevétel 1 fokú ortogonális polinom & $-5,1 \mathrm{E}-03$ & $6,3 E-03$ & $-1,6 E-02$ & $2,9 \mathrm{E}-02$ \\
\hline 0-1 eFt kategória logaritmusa & $6,3 E+00$ & $3,0 \mathrm{E}+00$ & $-2,7 \mathrm{E}-03$ & $1,6 \mathrm{E}+01$ \\
\hline 1-5 eFt kategória logaritmusa & $6,4 \mathrm{E}+00$ & $2,4 \mathrm{E}+00$ & $-2,7 \mathrm{E}-03$ & $1,6 \mathrm{E}+01$ \\
\hline 5-10 eFt kategória logaritmusa & $3,9 E+00$ & $2,6 \mathrm{E}+00$ & $-2,7 \mathrm{E}-03$ & $1,4 \mathrm{E}+01$ \\
\hline 10-20 eFt kategória logaritmusa & $2,7 E+00$ & $2,6 \mathrm{E}+00$ & $-2,7 \mathrm{E}-03$ & $1,3 \mathrm{E}+01$ \\
\hline 20- eFt kategória logaritmusa & $2,0 \mathrm{E}+00$ & $2,4 \mathrm{E}+00$ & $-2,7 \mathrm{E}-03$ & $1,3 \mathrm{E}+01$ \\
\hline Átlagos tételszám & $1,9 \mathrm{E}+00$ & $1,5 \mathrm{E}+00$ & $0,0 \mathrm{E}+00$ & $3,5 \mathrm{E}+02$ \\
\hline Átlagos fizetési érték & $6,7 E+03$ & $5,8 \mathrm{E}+04$ & $1,0 \mathrm{E}+00$ & $4,9 \mathrm{E}+07$ \\
\hline 0-1 eFt kategória aránya & $4,3 E-01$ & $3,2 E-01$ & $0,0 \mathrm{E}+00$ & $1,0 \mathrm{E}+00$ \\
\hline 1-5 eFt kategória aránya & $3,6 \mathrm{E}-01$ & $2,2 \mathrm{E}-01$ & $0,0 \mathrm{E}+00$ & $1,0 \mathrm{E}+00$ \\
\hline 5-10 eFt kategória aránya & $9,0 \mathrm{E}-02$ & $1,2 \mathrm{E}-01$ & $0,0 \mathrm{E}+00$ & $1,0 \mathrm{E}+00$ \\
\hline 10-20 eFt kategória aránya & $5,6 \mathrm{E}-02$ & $1,1 \mathrm{E}-01$ & $0,0 \mathrm{E}+00$ & $1,0 \mathrm{E}+00$ \\
\hline Hálózat teljes bevétele & $1,8 \mathrm{E}+01$ & $2,4 \mathrm{E}+00$ & $1,5 \mathrm{E}+01$ & $2,8 \mathrm{E}+01$ \\
\hline Hálózati boltok száma & $5,8 \mathrm{E}+01$ & $3,4 \mathrm{E}+02$ & $1,0 \mathrm{E}+00$ & $3,0 E+03$ \\
\hline Hétfői zárva tartás & $1,8 \mathrm{E}-01$ & $3,9 \mathrm{E}-01$ & $0,0 \mathrm{E}+00$ & $1,0 \mathrm{E}+00$ \\
\hline Keddi zárva tartás & $1,4 \mathrm{E}-01$ & $3,5 \mathrm{E}-01$ & $0,0 \mathrm{E}+00$ & $1,0 \mathrm{E}+00$ \\
\hline Vasárnapi nyitva tartás & $6,6 \mathrm{E}-01$ & $4,7 \mathrm{E}-01$ & $0,0 \mathrm{E}+00$ & $1,0 \mathrm{E}+00$ \\
\hline Keresztszorzat hétfői zárva tartás & $3,1 \mathrm{E}+00$ & $6,5 E+00$ & $0,0 E+00$ & $2,4 \mathrm{E}+01$ \\
\hline Keresztszorzat keddi zárva tartás & $2,4 \mathrm{E}+00$ & $6,0 E+00$ & $0,0 \mathrm{E}+00$ & $2,4 \mathrm{E}+01$ \\
\hline Keresztszorzat vasárnapi zárva tartás & $1,1 \mathrm{E}+01$ & $8,1 \mathrm{E}+00$ & $0,0 \mathrm{E}+00$ & $2,5 E+01$ \\
\hline Keresztszorzat hálózati üzletek száma & $9,5 \mathrm{E}+02$ & $5,4 \mathrm{E}+03$ & $1,5 \mathrm{E}+01$ & $5,8 \mathrm{E}+04$ \\
\hline Keresztszorzat hálózati teljes bevétel & $3,1 \mathrm{E}+02$ & $6,5 E+01$ & $2,1 \mathrm{E}+02$ & $6,7 \mathrm{E}+02$ \\
\hline
\end{tabular}


3. melléklet: A fő modellek együtthatói

\begin{tabular}{|c|c|c|c|c|c|c|}
\hline & $\begin{array}{c}\text { Csak } \\
\text { a méret } \\
\text { összevont } \\
\text { mintán }\end{array}$ & $\begin{array}{c}\text { Csak } \\
\text { a méret } \\
\text { havi bontás }\end{array}$ & $\begin{array}{c}\text { Teljes } \\
\text { modell } \\
\text { összevont } \\
\text { mintán }\end{array}$ & $\begin{array}{c}\text { Teljes } \\
\text { modell havi } \\
\text { bontás }\end{array}$ & $\begin{array}{l}\text { Kereszt- } \\
\text { szorzatok } \\
\text { összevont } \\
\text { mintán }\end{array}$ & $\begin{array}{c}\text { Kereszt- } \\
\text { szorzatok } \\
\text { havi bontás }\end{array}$ \\
\hline Konstans & $\begin{array}{l}-13,068 \\
(-8,174)\end{array}$ & $\begin{array}{l}-10,474 \\
(-1,923)\end{array}$ & $\begin{array}{l}-12,492 \\
(-0,050)\end{array}$ & $\begin{array}{l}-10,801 \\
(-0,012)\end{array}$ & $\begin{array}{l}-27,552 \\
(-0,111)\end{array}$ & $\begin{array}{l}-26,248 \\
(-0,030)\end{array}$ \\
\hline $\begin{array}{l}\text { Éves bevétel } 1 \text { fokú ortogonális } \\
\text { polinom }\end{array}$ & $\begin{array}{c}1569,077 \\
(9,016)\end{array}$ & $\begin{array}{c}1256,704 \\
(2,115)\end{array}$ & $\begin{array}{l}137,895 \\
(43,194)\end{array}$ & $\begin{array}{l}109,014 \\
(9,716)\end{array}$ & $\begin{array}{l}-382,139 \\
(-10,875)\end{array}$ & $\begin{array}{l}-287,557 \\
(-2,144)\end{array}$ \\
\hline $\begin{array}{l}\text { Éves bevétel } 2 \text { fokú ortogonális } \\
\text { polinom }\end{array}$ & $\begin{array}{c}-1573,727 \\
(-7,816)\end{array}$ & $\begin{array}{c}-1226,946 \\
(-1,789)\end{array}$ & $\begin{array}{l}-63,635 \\
(-38,029)\end{array}$ & $\begin{array}{l}-71,990 \\
(-11,916)\end{array}$ & $\begin{array}{l}-160,482 \\
(-64,993)\end{array}$ & $\begin{array}{l}-158,770 \\
(-17,560)\end{array}$ \\
\hline $\begin{array}{l}\text { Éves bevétel 3fokú ortogonális } \\
\text { polinom }\end{array}$ & $\begin{array}{c}1463,783 \\
(8,069)\end{array}$ & $\begin{array}{c}1 \text { 138,491 } \\
(1,836)\end{array}$ & $\begin{array}{c}22,648 \\
(15,388)\end{array}$ & $\begin{array}{l}20,016 \\
(3,948)\end{array}$ & $\begin{array}{l}10,659 \\
(5,786)\end{array}$ & $\begin{array}{c}7,012 \\
(1,084)\end{array}$ \\
\hline 0-1 eFt kategória logaritmusa & & & $\begin{array}{c}0,039 \\
(6,477)\end{array}$ & $\begin{array}{c}0,037 \\
(1,706)\end{array}$ & $\begin{array}{c}0,016 \\
(2,543)\end{array}$ & $\begin{array}{c}0,015 \\
(0,685)\end{array}$ \\
\hline 1-5 eFt kategória logaritmusa & & & $\begin{array}{c}0,103 \\
(9,602)\end{array}$ & $\begin{array}{c}0,121 \\
(3,114)\end{array}$ & $\begin{array}{c}0,130 \\
(11,961)\end{array}$ & $\begin{array}{c}0,132 \\
(3,365)\end{array}$ \\
\hline 5-10 eFt kategória logaritmusa & & & $\begin{array}{c}0,124 \\
(14,477)\end{array}$ & $\begin{array}{c}0,085 \\
(2,768)\end{array}$ & $\begin{array}{c}0,110 \\
(12,795)\end{array}$ & $\begin{array}{c}0,073 \\
(2,366)\end{array}$ \\
\hline $\begin{array}{l}\text { 10-20 eFt kategória } \\
\text { logaritmusa }\end{array}$ & & & $\begin{array}{c}0,045 \\
(6,930)\end{array}$ & $\begin{array}{c}0,033 \\
(1,430)\end{array}$ & $\begin{array}{c}0,038 \\
(5,886)\end{array}$ & $\begin{array}{c}0,021 \\
(0,878)\end{array}$ \\
\hline 20- eFt kategória logaritmusa & & & $\begin{array}{c}0,092 \\
(17,804)\end{array}$ & $\begin{array}{c}0,105 \\
(5,641)\end{array}$ & $\begin{array}{c}0,137 \\
(26,033)\end{array}$ & $\begin{array}{c}0,147 \\
(7,699)\end{array}$ \\
\hline $\begin{array}{l}\text { 0-1 eFt kategória } \\
\text { logaritmusának négyzete }\end{array}$ & & & $\begin{array}{c}0,020 \\
(24,818)\end{array}$ & $\begin{array}{c}0,025 \\
(8,491)\end{array}$ & $\begin{array}{c}0,024 \\
(28,800)\end{array}$ & $\begin{array}{c}0,028 \\
(9,215)\end{array}$ \\
\hline $\begin{array}{l}\text { 1-5 eFt kategória } \\
\text { logaritmusának négyzete }\end{array}$ & & & $\begin{array}{c}-0,023 \\
(-19,448)\end{array}$ & $\begin{array}{l}-0,020 \\
(-4,633)\end{array}$ & $\begin{array}{c}-0,027 \\
(-22,999)\end{array}$ & $\begin{array}{l}-0,023 \\
(-5,302)\end{array}$ \\
\hline $\begin{array}{l}\text { 5-10 eFt kategória } \\
\text { logaritmusának négyzete }\end{array}$ & & & $\begin{array}{c}-0,027 \\
(-22,693)\end{array}$ & $\begin{array}{c}-0,031 \\
(-7,283)\end{array}$ & $\begin{array}{c}-0,026 \\
(-21,481)\end{array}$ & $\begin{array}{c}-0,031 \\
(-7,185)\end{array}$ \\
\hline $\begin{array}{l}\text { 10-20 eFt kategória } \\
\text { logaritmusának négyzete }\end{array}$ & & & $\begin{array}{c}0,042 \\
(34,785)\end{array}$ & $\begin{array}{c}0,057 \\
(12,929)\end{array}$ & $\begin{array}{c}0,045 \\
(36,764)\end{array}$ & $\begin{array}{c}0,062 \\
(13,861)\end{array}$ \\
\hline $\begin{array}{l}\text { 20- eFt kategória } \\
\text { logaritmusának négyzete }\end{array}$ & & & $\begin{array}{c}-0,041 \\
(-35,834)\end{array}$ & $\begin{array}{c}-0,053 \\
(-12,290)\end{array}$ & $\begin{array}{c}-0,052 \\
(-43,241)\end{array}$ & $\begin{array}{c}-0,063 \\
(-13,970)\end{array}$ \\
\hline Átlagos tételszám & & & $\begin{array}{c}-0,025 \\
(-10,502)\end{array}$ & $\begin{array}{l}-0,037 \\
(-4,341)\end{array}$ & $\begin{array}{l}-0,009 \\
(-3,356)\end{array}$ & $\begin{array}{l}-0,023 \\
(-2,412)\end{array}$ \\
\hline Átlagos fizetési érték & & & $\begin{array}{c}0,000 \\
(-20,028)\end{array}$ & $\begin{array}{c}0,000 \\
(-4,198)\end{array}$ & $\begin{array}{c}0,000 \\
(-19,345)\end{array}$ & $\begin{array}{c}0,000 \\
(-4,161)\end{array}$ \\
\hline 0-1 eFt kategória aránya & & & $\begin{array}{l}-0,640 \\
(-6,450)\end{array}$ & $\begin{array}{l}-1,544 \\
(-4,366)\end{array}$ & $\begin{array}{l}-0,486 \\
(-4,869)\end{array}$ & $\begin{array}{l}-1,317 \\
(-3,702)\end{array}$ \\
\hline 1-5 eFt kategória aránya & & & $\begin{array}{c}-1,123 \\
(-10,618)\end{array}$ & $\begin{array}{l}-1,913 \\
(-5,042)\end{array}$ & $\begin{array}{c}-1,278 \\
(-12,034)\end{array}$ & $\begin{array}{c}-1,964 \\
(-5,158)\end{array}$ \\
\hline 5-10 eFt kategória aránya & & & $\begin{array}{c}2,680 \\
(20,558)\end{array}$ & $\begin{array}{c}3,187 \\
(6,824)\end{array}$ & $\begin{array}{c}2,862 \\
(21,806)\end{array}$ & $\begin{array}{c}3,411 \\
(7,248)\end{array}$ \\
\hline 10-20 eFt kategória aránya & & & $\begin{array}{c}1,880 \\
(17,003)\end{array}$ & $\begin{array}{c}1,060 \\
(2,740)\end{array}$ & $\begin{array}{c}1,631 \\
(14,732)\end{array}$ & $\begin{array}{c}0,793 \\
(2,044)\end{array}$ \\
\hline
\end{tabular}




\begin{tabular}{|c|c|c|c|c|c|c|}
\hline & $\begin{array}{c}\text { Csak } \\
\text { a méret } \\
\text { összevont } \\
\text { mintán }\end{array}$ & $\begin{array}{c}\text { Csak } \\
\text { a méret } \\
\text { havi bontás }\end{array}$ & $\begin{array}{c}\text { Teljes } \\
\text { modell } \\
\text { összevont } \\
\text { mintán }\end{array}$ & $\begin{array}{c}\text { Teljes } \\
\text { modell havi } \\
\text { bontás }\end{array}$ & $\begin{array}{l}\text { Kereszt- } \\
\text { szorzatok } \\
\text { összevont } \\
\text { mintán }\end{array}$ & $\begin{array}{c}\text { Kereszt- } \\
\text { szorzatok } \\
\text { havi bontás }\end{array}$ \\
\hline $\begin{array}{l}0-1 \text { eFt kategória arány } \\
\text { négyzete }\end{array}$ & & & $\begin{array}{c}-3,682 \\
(-41,924) \\
\end{array}$ & $\begin{array}{c}-3,554 \\
(-11,425) \\
\end{array}$ & $\begin{array}{c}-4,036 \\
(-45,505) \\
\end{array}$ & $\begin{array}{c}-3,970 \\
(-12,624) \\
\end{array}$ \\
\hline $\begin{array}{l}\text { 1-5 eFt kategória arány } \\
\text { négyzete }\end{array}$ & & & $\begin{array}{c}0,701 \\
(7,568)\end{array}$ & $\begin{array}{c}0,875 \\
(2,659)\end{array}$ & $\begin{array}{l}0,896 \\
(9,654)\end{array}$ & $\begin{array}{c}0,997 \\
(3,027)\end{array}$ \\
\hline $\begin{array}{l}\text { 5-10 eFt kategória arány } \\
\text { négyzete }\end{array}$ & & & $\begin{array}{c}-6,377 \\
(-30,918)\end{array}$ & $\begin{array}{c}-7,778 \\
(-10,391)\end{array}$ & $\begin{array}{c}-6,776 \\
(-32,481)\end{array}$ & $\begin{array}{c}-8,207 \\
(-10,837)\end{array}$ \\
\hline $\begin{array}{l}\text { 10-20 eft kategória arány } \\
\text { négyzete }\end{array}$ & & & $\begin{array}{c}-3,128 \\
(-24,361)\end{array}$ & $\begin{array}{l}-2,716 \\
(-6,180)\end{array}$ & $\begin{array}{c}-2,959 \\
(-23,013)\end{array}$ & $\begin{array}{l}-2,526 \\
(-5,731)\end{array}$ \\
\hline Hálózat teljes bevétele & & & $\begin{array}{c}-0,301 \\
(-9,965)\end{array}$ & $\begin{array}{l}-0,481 \\
(-4,184) \\
\end{array}$ & $\begin{array}{c}0,287 \\
(0,990)\end{array}$ & $\begin{array}{c}1,014 \\
(0,916)\end{array}$ \\
\hline $\begin{array}{l}\text { Hálózat teljes bevételének } \\
\text { négyzete }\end{array}$ & & & $\begin{array}{c}0,015 \\
(19,271)\end{array}$ & $\begin{array}{c}0,020 \\
(6,844)\end{array}$ & $\begin{array}{c}-0,084 \\
(-10,660)\end{array}$ & $\begin{array}{l}-0,098 \\
(-3,244)\end{array}$ \\
\hline Hálózati boltok száma & & & $\begin{array}{c}-0,007 \\
(-54,065)\end{array}$ & $\begin{array}{c}-0,010 \\
(-17,006)\end{array}$ & $\begin{array}{c}0,091 \\
(68,225)\end{array}$ & $\begin{array}{c}0,097 \\
(14,733)\end{array}$ \\
\hline $\begin{array}{l}\text { Hálózati boltok számának } \\
\text { négyzete }\end{array}$ & & & $\begin{array}{c}0,000 \\
(43,612)\end{array}$ & $\begin{array}{c}0,000 \\
(12,189)\end{array}$ & $\begin{array}{c}0,000 \\
(-45,599)\end{array}$ & $\begin{array}{c}0,000 \\
(-3,180)\end{array}$ \\
\hline Hétfői zárvatartás & & & $\begin{array}{c}-0,661 \\
(-58,244)\end{array}$ & $\begin{array}{c}-0,637 \\
(-15,986)\end{array}$ & $\begin{array}{c}0,200 \\
(1,058)\end{array}$ & $\begin{array}{l}-0,529 \\
(-0,798)\end{array}$ \\
\hline Keddi zárvatartás & & & $\begin{array}{c}-0,590 \\
(-37,402)\end{array}$ & $\begin{array}{c}-0,735 \\
(-12,278)\end{array}$ & $\begin{array}{c}0,285 \\
(1,115)\end{array}$ & $\begin{array}{l}-1,490 \\
(-1,491)\end{array}$ \\
\hline Vasárnapi zárvatartás & & & $\begin{array}{c}-0,134 \\
(-22,699)\end{array}$ & $\begin{array}{c}-0,063 \\
(-2,961)\end{array}$ & $\begin{array}{c}-0,822 \\
(-9,821)\end{array}$ & $\begin{array}{l}-0,956 \\
(-3,251)\end{array}$ \\
\hline Megye: Mozgóbolt & & & $\begin{array}{c}-0,827 \\
(-32,574)\end{array}$ & $\begin{array}{l}-0,841 \\
(-9,056)\end{array}$ & $\begin{array}{c}-0,807 \\
(-31,544)\end{array}$ & $\begin{array}{c}-0,822 \\
(-8,799)\end{array}$ \\
\hline Megye: Bács-Kiskun & & & $\begin{array}{c}0,428 \\
(30,770)\end{array}$ & $\begin{array}{c}0,379 \\
(7,743)\end{array}$ & $\begin{array}{c}0,445 \\
(31,897)\end{array}$ & $\begin{array}{c}0,400 \\
(8,163)\end{array}$ \\
\hline Megye: Baranya & & & $\begin{array}{c}0,162 \\
(9,087)\end{array}$ & $\begin{array}{c}0,099 \\
(1,588)\end{array}$ & $\begin{array}{c}0,169 \\
(9,463)\end{array}$ & $\begin{array}{c}0,106 \\
(1,691)\end{array}$ \\
\hline Megye: Békés & & & $\begin{array}{c}-0,466 \\
(-27,580) \\
\end{array}$ & $\begin{array}{l}-0,534 \\
(-8,974)\end{array}$ & $\begin{array}{c}-0,465 \\
(-27,464) \\
\end{array}$ & $\begin{array}{l}-0,527 \\
(-8,816) \\
\end{array}$ \\
\hline Megye: Borsod-Abaúj-Zemplén & & & $\begin{array}{c}-0,390 \\
(-20,742)\end{array}$ & $\begin{array}{c}-0,457 \\
(-6,868)\end{array}$ & $\begin{array}{c}-0,391 \\
(-20,686)\end{array}$ & $\begin{array}{c}-0,451 \\
(-6,744)\end{array}$ \\
\hline Megye: Budapest & & & $\begin{array}{c}-0,134 \\
(-8,023)\end{array}$ & $\begin{array}{c}-0,189 \\
(-3,216)\end{array}$ & $\begin{array}{c}-0,138 \\
(-8,240)\end{array}$ & $\begin{array}{c}-0,197 \\
(-3,330)\end{array}$ \\
\hline Megye: Csongrád & & & $\begin{array}{c}0,145 \\
(8,395) \\
\end{array}$ & $\begin{array}{c}0,105 \\
(1,740) \\
\end{array}$ & $\begin{array}{c}0,144 \\
(8,307) \\
\end{array}$ & $\begin{array}{c}0,114 \\
(1,879) \\
\end{array}$ \\
\hline Megye: Fejér & & & $\begin{array}{c}0,255 \\
(14,371) \\
\end{array}$ & $\begin{array}{c}0,199 \\
(3,193) \\
\end{array}$ & $\begin{array}{c}0,257 \\
(14,462) \\
\end{array}$ & $\begin{array}{c}0,204 \\
(3,272) \\
\end{array}$ \\
\hline Megye: Győr-Moson-Sopron & & & $\begin{array}{c}-0,372 \\
(-22,301)\end{array}$ & $\begin{array}{c}-0,441 \\
(-7,532)\end{array}$ & $\begin{array}{c}-0,375 \\
(-22,405)\end{array}$ & $\begin{array}{c}-0,437 \\
(-7,429)\end{array}$ \\
\hline Megye: Hajdú-Bihar & & & $\begin{array}{c}-0,007 \\
(-0,405)\end{array}$ & $\begin{array}{c}-0,050 \\
(-0,857)\end{array}$ & $\begin{array}{c}0,004 \\
(0,223)\end{array}$ & $\begin{array}{c}-0,035 \\
(-0,590)\end{array}$ \\
\hline
\end{tabular}




\begin{tabular}{|c|c|c|c|c|c|c|}
\hline & $\begin{array}{l}\text { Csak } \\
\text { a méret } \\
\text { összevont } \\
\text { mintán }\end{array}$ & $\begin{array}{c}\text { Csak } \\
\text { a méret } \\
\text { havi bontás }\end{array}$ & $\begin{array}{c}\text { Teljes } \\
\text { modell } \\
\text { összevont } \\
\text { mintán }\end{array}$ & $\begin{array}{c}\text { Teljes } \\
\text { modell havi } \\
\text { bontás }\end{array}$ & $\begin{array}{c}\text { Kereszt- } \\
\text { szorzatok } \\
\text { összevont } \\
\text { mintán }\end{array}$ & $\begin{array}{l}\text { Kereszt- } \\
\text { szorzatok } \\
\text { havi bontás }\end{array}$ \\
\hline Megye: Heves & & & $\begin{array}{l}-0,007 \\
(-0,400)\end{array}$ & $\begin{array}{l}-0,097 \\
(-1,478)\end{array}$ & $\begin{array}{l}-0,010 \\
(-0,519)\end{array}$ & $\begin{array}{l}-0,095 \\
(-1,441)\end{array}$ \\
\hline Megye: Jász-Nagykun-Szolnok & & & $\begin{array}{c}0,394 \\
(21,123)\end{array}$ & $\begin{array}{c}0,327 \\
(4,975)\end{array}$ & $\begin{array}{c}0,398 \\
(21,285)\end{array}$ & $\begin{array}{c}0,337 \\
(5,132)\end{array}$ \\
\hline Megye: Komárom-Esztergom & & & $\begin{array}{c}-0,330 \\
(-13,709)\end{array}$ & $\begin{array}{l}-0,383 \\
(-4,531)\end{array}$ & $\begin{array}{c}-0,339 \\
(-14,005)\end{array}$ & $\begin{array}{l}-0,391 \\
(-4,588)\end{array}$ \\
\hline Megye: Nógrád & & & $\begin{array}{c}0,083 \\
(5,569)\end{array}$ & $\begin{array}{c}0,020 \\
(0,383)\end{array}$ & $\begin{array}{c}0,084 \\
(5,621)\end{array}$ & $\begin{array}{c}0,028 \\
(0,529)\end{array}$ \\
\hline Megye: Pest & & & $\begin{array}{c}-0,275 \\
(-14,691)\end{array}$ & $\begin{array}{l}-0,286 \\
(-4,232)\end{array}$ & $\begin{array}{c}-0,277 \\
(-14,725)\end{array}$ & $\begin{array}{l}-0,286 \\
(-4,217)\end{array}$ \\
\hline Megye: Somogy & & & $\begin{array}{c}-0,697 \\
(-39,108)\end{array}$ & $\begin{array}{c}-0,799 \\
(-12,647)\end{array}$ & $\begin{array}{c}-0,703 \\
(-39,251)\end{array}$ & $\begin{array}{c}-0,803 \\
(-12,655)\end{array}$ \\
\hline $\begin{array}{l}\text { Megye: Szabolcs-Szatmár- } \\
\text { Bereg }\end{array}$ & & & $\begin{array}{l}-0,181 \\
(-9,912)\end{array}$ & $\begin{array}{l}-0,238 \\
(-3,688)\end{array}$ & $\begin{array}{l}-0,183 \\
(-9,963)\end{array}$ & $\begin{array}{c}-0,237 \\
(-3,657)\end{array}$ \\
\hline Megye: Tolna & & & $\begin{array}{l}-0,126 \\
(-6,199)\end{array}$ & $\begin{array}{l}-0,208 \\
(-2,911)\end{array}$ & $\begin{array}{l}-0,132 \\
(-6,471)\end{array}$ & $\begin{array}{l}-0,210 \\
(-2,933)\end{array}$ \\
\hline Megye: Vas & & & $\begin{array}{c}-0,529 \\
(-26,831)\end{array}$ & $\begin{array}{c}-0,621 \\
(-8,880)\end{array}$ & $\begin{array}{c}-0,544 \\
(-27,391)\end{array}$ & $\begin{array}{c}-0,630 \\
(-8,953)\end{array}$ \\
\hline Megye: Veszprém & & & $\begin{array}{c}0,151 \\
(8,651)\end{array}$ & $\begin{array}{c}0,124 \\
(2,002)\end{array}$ & $\begin{array}{c}0,156 \\
(8,934)\end{array}$ & $\begin{array}{c}0,132 \\
(2,123)\end{array}$ \\
\hline \multicolumn{7}{|l|}{ Megye: Zala } \\
\hline Dummy változó 2016 1. hónap & $\begin{array}{c}-0,254 \\
(-24,314)\end{array}$ & & $\begin{array}{c}-0,112 \\
(-9,363)\end{array}$ & & $\begin{array}{c}-0,111 \\
(-9,245)\end{array}$ & \\
\hline Dummy változó 2016 2. hónap & $\begin{array}{c}-0,066 \\
(-6,449)\end{array}$ & & $\begin{array}{c}0,027 \\
(2,296)\end{array}$ & & $\begin{array}{c}0,030 \\
(2,551)\end{array}$ & \\
\hline Dummy változó 2016 3. hónap & $\begin{array}{c}-0,048 \\
(-4,661)\end{array}$ & & $\begin{array}{c}0,050 \\
(4,326)\end{array}$ & & $\begin{array}{c}0,054 \\
(4,644)\end{array}$ & \\
\hline \multicolumn{7}{|l|}{ Dummy változó 2016 4. hónap } \\
\hline Dummy változó 2016 5. hónap & $\begin{array}{c}-0,237 \\
(-22,711)\end{array}$ & & $\begin{array}{c}-0,101 \\
(-8,509)\end{array}$ & & $\begin{array}{c}-0,100 \\
(-8,369)\end{array}$ & \\
\hline Dummy változó 2016 6. hónap & $\begin{array}{c}-0,207 \\
(-20,017)\end{array}$ & & $\begin{array}{c}-0,115 \\
(-9,808)\end{array}$ & & $\begin{array}{c}-0,115 \\
(-9,759)\end{array}$ & \\
\hline Dummy változó 2016 7. hónap & $\begin{array}{c}-0,201 \\
(-19,469)\end{array}$ & & $\begin{array}{c}-0,073 \\
(-6,239)\end{array}$ & & $\begin{array}{c}-0,069 \\
(-5,916)\end{array}$ & \\
\hline Dummy változó 2016 8. hónap & $\begin{array}{c}-0,185 \\
(-18,030)\end{array}$ & & $\begin{array}{c}-0,076 \\
(-6,525)\end{array}$ & & $\begin{array}{c}-0,072 \\
(-6,153)\end{array}$ & \\
\hline Dummy változó 2016 9. hónap & $\begin{array}{c}-0,175 \\
(-17,067)\end{array}$ & & $\begin{array}{c}-0,059 \\
(-5,096)\end{array}$ & & $\begin{array}{c}-0,054 \\
(-4,680)\end{array}$ & \\
\hline $\begin{array}{l}\text { Dummy változó } 201610 . \\
\text { hónap }\end{array}$ & $\begin{array}{c}-0,129 \\
(-12,602)\end{array}$ & & $\begin{array}{l}-0,024 \\
(-2,038)\end{array}$ & & $\begin{array}{l}-0,019 \\
(-1,664)\end{array}$ & \\
\hline
\end{tabular}




\begin{tabular}{|c|c|c|c|c|c|c|}
\hline & $\begin{array}{c}\text { Csak } \\
\text { a méret } \\
\text { összevont } \\
\text { mintán }\end{array}$ & $\begin{array}{c}\text { Csak } \\
\text { a méret } \\
\text { havi bontás }\end{array}$ & $\begin{array}{c}\text { Teljes } \\
\text { modell } \\
\text { összevont } \\
\text { mintán }\end{array}$ & $\begin{array}{c}\text { Teljes } \\
\text { modell havi } \\
\text { bontás }\end{array}$ & $\begin{array}{c}\text { Kereszt- } \\
\text { szorzatok } \\
\text { összevont } \\
\text { mintán }\end{array}$ & $\begin{array}{c}\text { Kereszt- } \\
\text { szorzatok } \\
\text { havi bontás }\end{array}$ \\
\hline $\begin{array}{l}\text { Dummy változó } 201611 . \\
\text { hónap }\end{array}$ & $\begin{array}{c}-0,114 \\
(-11,147) \\
\end{array}$ & & $\begin{array}{l}-0,029 \\
(-2,543)\end{array}$ & & $\begin{array}{l}-0,025 \\
(-2,147)\end{array}$ & \\
\hline $\begin{array}{l}\text { Dummy változó } 201612 . \\
\text { hónap }\end{array}$ & $\begin{array}{c}-0,114 \\
(-11,176)\end{array}$ & & $\begin{array}{c}0,028 \\
(2,461)\end{array}$ & & $\begin{array}{c}0,035 \\
(3,048)\end{array}$ & \\
\hline \multicolumn{7}{|l|}{$\begin{array}{l}\text { Dummy változó hálózati } \\
\text { döntésű üzlet }\end{array}$} \\
\hline Dummy változó egyedi üzlet & & & $\begin{array}{c}0,390 \\
(52,267)\end{array}$ & $\begin{array}{c}0,434 \\
(16,335)\end{array}$ & $\begin{array}{c}0,449 \\
(52,668)\end{array}$ & $\begin{array}{c}0,470 \\
(15,379)\end{array}$ \\
\hline $\begin{array}{l}\text { Dummy változó egyedi döntésú } \\
\text { üzlet }\end{array}$ & & & $\begin{array}{c}1,137 \\
(155,031) \\
\end{array}$ & $\begin{array}{c}1,217 \\
(45,851) \\
\end{array}$ & $\begin{array}{c}1,139 \\
(152,954) \\
\end{array}$ & $\begin{array}{c}1,204 \\
(44,595) \\
\end{array}$ \\
\hline $\begin{array}{l}\text { Keresztszorzat hétfői } \\
\text { zárvatartás }\end{array}$ & & & & & $\begin{array}{l}-0,050 \\
(-4,543)\end{array}$ & $\begin{array}{l}-0,006 \\
(-0,168)\end{array}$ \\
\hline $\begin{array}{l}\text { Keresztszorzat keddi } \\
\text { zárvatartás }\end{array}$ & & & & & $\begin{array}{l}-0,050 \\
(-3,410)\end{array}$ & $\begin{array}{c}0,043 \\
(0,752)\end{array}$ \\
\hline $\begin{array}{l}\text { Keresztszorzat vasárnapi } \\
\text { zárvatartás }\end{array}$ & & & & & $\begin{array}{c}0,038 \\
(8,007)\end{array}$ & $\begin{array}{c}0,050 \\
(2,991)\end{array}$ \\
\hline $\begin{array}{l}\text { Keresztszorzat hálózati üzletek } \\
\text { száma }\end{array}$ & & & & & $\begin{array}{c}-0,005 \\
(-71,994)\end{array}$ & $\begin{array}{c}-0,006 \\
(-14,647)\end{array}$ \\
\hline $\begin{array}{l}\text { Keresztszorzat hálózati teljes } \\
\text { bevétel }\end{array}$ & & & & & $\begin{array}{c}0,039 \\
(2,470)\end{array}$ & $\begin{array}{l}-0,005 \\
(-0,083)\end{array}$ \\
\hline $\begin{array}{l}\text { Éves bevétel } 4 \text { fokú ortogonális } \\
\text { polinom }\end{array}$ & $\begin{array}{c}-1211,598 \\
(-7,313)\end{array}$ & $\begin{array}{c}-939,773 \\
(-1,667)\end{array}$ & & & & \\
\hline $\begin{array}{l}\text { Éves bevétel } 5 \text { fokú ortogonális } \\
\text { polinom }\end{array}$ & $\begin{array}{c}970,584 \\
(8,547)\end{array}$ & $\begin{array}{c}767,118 \\
(1,971)\end{array}$ & & & & \\
\hline $\begin{array}{l}\text { Éves bevétel } 6 \text { fokú ortogonális } \\
\text { polinom }\end{array}$ & $\begin{array}{c}-648,841 \\
(-7,059)\end{array}$ & $\begin{array}{r}-510,047 \\
(-1,633)\end{array}$ & & & & \\
\hline $\begin{array}{l}\text { Éves bevétel } 7 \text { fokú ortogonális } \\
\text { polinom }\end{array}$ & $\begin{array}{r}415,525 \\
(9,190)\end{array}$ & $\begin{array}{r}336,030 \\
(2,162)\end{array}$ & & & & \\
\hline $\begin{array}{l}\text { Éves bevétel } 8 \text { fokú ortogonális } \\
\text { polinom }\end{array}$ & $\begin{array}{r}-214,536 \\
(-6,480)\end{array}$ & $\begin{array}{r}-170,405 \\
(-1,518) \\
\end{array}$ & & & & \\
\hline $\begin{array}{l}\text { Éves bevétel } 9 \text { fokú ortogonális } \\
\text { polinom }\end{array}$ & $\begin{array}{c}98,416 \\
(11,105)\end{array}$ & $\begin{array}{l}83,588 \\
(2,734)\end{array}$ & & & & \\
\hline $\begin{array}{l}\text { Éves bevétel } 10 \text { fokú } \\
\text { ortogonális polinom }\end{array}$ & $\begin{array}{l}-26,204 \\
(-4,091)\end{array}$ & $\begin{array}{l}-19,092 \\
(-0,881)\end{array}$ & & & & \\
\hline
\end{tabular}

Megjegyzés: Havi bontású modellek esetén minden hónapra külön becsültük a regressziós paraméterek értékét, azonban azok kevés szóródást mutatnak. Terjedelmi korlátok miatt a táblázatban csak egy reprezentatív hónap (2016. március) értékei szerepelnek, amelyek jól jellemzik az adott modellcsoport eredményeit.

A zárójelben az adott változók z-statisztikái szerepelnek. 


\section{4. melléklet: Az értékkategória-arányok hatásai a modellben}

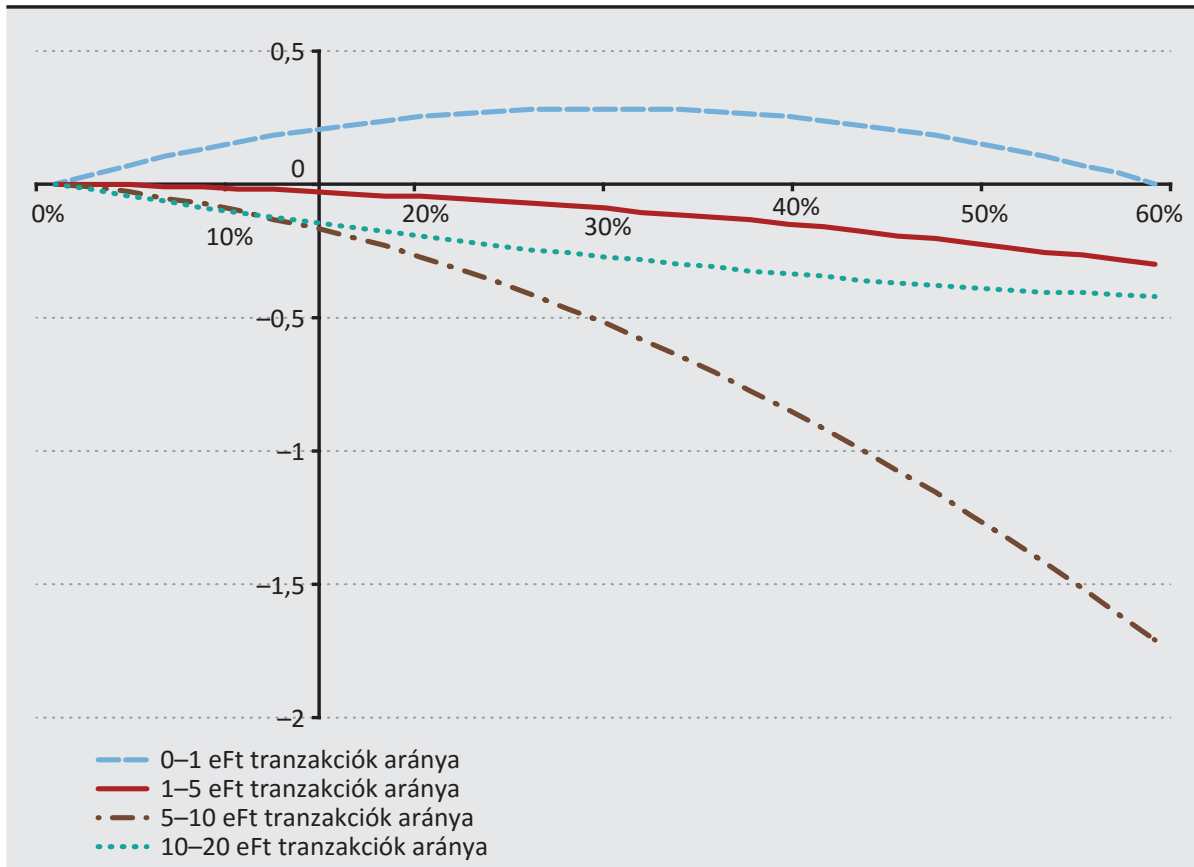

Megjegyzés: Függöleges tengely: a számolt hatás a magyarázó változók skáláján számolva, vízzzintes tengely: az adott kategória részaránya a forgalomból.

\section{5. melléklet: Az almintákon becsült modellek együtthatói}

\begin{tabular}{|c|c|c|c|c|c|c|}
\hline & $\begin{array}{l}\text { Hálózati } \\
\text { döntésű } \\
\text { üzletek }\end{array}$ & $\begin{array}{l}\text { Egyedi } \\
\text { üzletek }\end{array}$ & $\begin{array}{l}\text { Egyedi } \\
\text { döntésú } \\
\text { üzletek }\end{array}$ & $\begin{array}{c}\text { Kis } \\
\text { méretü } \\
\text { üzletek }\end{array}$ & $\begin{array}{l}\text { Közepes } \\
\text { méretű } \\
\text { üzletek }\end{array}$ & $\begin{array}{c}\text { Nagy } \\
\text { méretú } \\
\text { üzletek }\end{array}$ \\
\hline Konstans & $\begin{array}{l}-20,428 \\
(-9,183)\end{array}$ & $\begin{array}{c}3053,212 \\
(1,007)\end{array}$ & $\begin{array}{c}57,684 \\
(13,695)\end{array}$ & $\begin{array}{l}-4,679 \\
(-0,006)\end{array}$ & $\begin{array}{l}-27,998 \\
(-6,462)\end{array}$ & $\begin{array}{c}57,684 \\
(13,695)\end{array}$ \\
\hline $\begin{array}{l}\text { Éves bevétel } 1 \text { fokú ortogonális } \\
\text { polinom }\end{array}$ & $\begin{array}{l}28,913 \\
(1,292)\end{array}$ & $\begin{array}{c}-5427,169 \\
(-1,130)\end{array}$ & $\begin{array}{c}146,156 \\
(5,582)\end{array}$ & $\begin{array}{l}509,814 \\
(2,562)\end{array}$ & $\begin{array}{l}979,621 \\
(3,821)\end{array}$ & $\begin{array}{l}146,156 \\
(5,582)\end{array}$ \\
\hline $\begin{array}{l}\text { Éves bevétel } 2 \text { fokú ortogonális } \\
\text { polinom }\end{array}$ & $\begin{array}{l}-81,554 \\
(-7,297)\end{array}$ & $\begin{array}{c}-7360,084 \\
(-1,372)\end{array}$ & $\begin{array}{l}-96,260 \\
(-6,655)\end{array}$ & $\begin{array}{l}57,609 \\
(1,067)\end{array}$ & $\begin{array}{c}-582,733 \\
(-3,770)\end{array}$ & $\begin{array}{l}-96,260 \\
(-6,655)\end{array}$ \\
\hline $\begin{array}{l}\text { Éves bevétel 3fokú ortogonális } \\
\text { polinom }\end{array}$ & $\begin{array}{l}22,229 \\
(2,121)\end{array}$ & $\begin{array}{l}31,719 \\
(4,037)\end{array}$ & $\begin{array}{l}-21,697 \\
(-1,843)\end{array}$ & $\begin{array}{l}194,475 \\
(2,166)\end{array}$ & $\begin{array}{l}277,567 \\
(3,853)\end{array}$ & $\begin{array}{l}-21,697 \\
(-1,843)\end{array}$ \\
\hline 0-1 eFt kategória logaritmusa & $\begin{array}{l}-0,108 \\
(-2,388)\end{array}$ & $\begin{array}{c}0,087 \\
(2,944)\end{array}$ & $\begin{array}{c}0,024 \\
(0,404)\end{array}$ & $\begin{array}{c}0,139 \\
(4,807)\end{array}$ & $\begin{array}{c}-0,189 \\
(-2,560)\end{array}$ & $\begin{array}{c}0,024 \\
(0,404)\end{array}$ \\
\hline 1-5 eFt kategória logaritmusa & $\begin{array}{c}0,279 \\
(3,363)\end{array}$ & $\begin{array}{c}0,089 \\
(1,717)\end{array}$ & $\begin{array}{c}-0,033 \\
(-0,320)\end{array}$ & $\begin{array}{c}0,102 \\
(1,984)\end{array}$ & $\begin{array}{c}0,075 \\
(0,594)\end{array}$ & $\begin{array}{c}-0,033 \\
(-0,320)\end{array}$ \\
\hline 5-10 eFt kategória logaritmusa & $\begin{array}{c}0,046 \\
(0,677)\end{array}$ & $\begin{array}{c}0,131 \\
(3,152)\end{array}$ & $\begin{array}{c}-0,139 \\
(-1,927)\end{array}$ & $\begin{array}{c}0,049 \\
(1,273)\end{array}$ & $\begin{array}{c}0,344 \\
(2,706)\end{array}$ & $\begin{array}{c}-0,139 \\
(-1,927)\end{array}$ \\
\hline
\end{tabular}




\begin{tabular}{|c|c|c|c|c|c|c|}
\hline & $\begin{array}{l}\text { Hálózati } \\
\text { döntésú } \\
\text { üzletek }\end{array}$ & $\begin{array}{l}\text { Egyedi } \\
\text { üzletek }\end{array}$ & $\begin{array}{l}\text { Egyedi } \\
\text { döntésú } \\
\text { üzletek }\end{array}$ & $\begin{array}{c}\text { Kis } \\
\text { méretú } \\
\text { üzletek }\end{array}$ & $\begin{array}{l}\text { Közepes } \\
\text { méretü } \\
\text { üzletek }\end{array}$ & $\begin{array}{l}\text { Nagy } \\
\text { méretü } \\
\text { üzletek }\end{array}$ \\
\hline $\begin{array}{l}\text { 10-20 eFt kategória } \\
\text { logaritmusa }\end{array}$ & $\begin{array}{l}-0,054 \\
(-1,030)\end{array}$ & $\begin{array}{c}0,061 \\
(1,921)\end{array}$ & $\begin{array}{c}0,082 \\
(1,464)\end{array}$ & $\begin{array}{c}0,038 \\
(1,213)\end{array}$ & $\begin{array}{l}-0,324 \\
(-3,413)\end{array}$ & $\begin{array}{c}0,082 \\
(1,464)\end{array}$ \\
\hline 20- eFt kategória logaritmusa & $\begin{array}{c}0,151 \\
(3,956)\end{array}$ & $\begin{array}{c}0,121 \\
(4,637)\end{array}$ & $\begin{array}{c}0,144 \\
(3,054)\end{array}$ & $\begin{array}{c}0,156 \\
(6,107)\end{array}$ & $\begin{array}{c}0,162 \\
(2,741)\end{array}$ & $\begin{array}{c}0,144 \\
(3,054)\end{array}$ \\
\hline $\begin{array}{l}\text { 0-1 eFt kategória } \\
\text { logaritmusának négyzete }\end{array}$ & $\begin{array}{c}0,079 \\
(13,024) \\
\end{array}$ & $\begin{array}{c}0,006 \\
(1,251)\end{array}$ & $\begin{array}{c}0,008 \\
(1,061)\end{array}$ & $\begin{array}{c}0,009 \\
(2,005)\end{array}$ & $\begin{array}{c}0,068 \\
(6,770)\end{array}$ & $\begin{array}{c}0,008 \\
(1,061)\end{array}$ \\
\hline $\begin{array}{l}\text { 1-5 eFt kategória } \\
\text { logaritmusának négyzete }\end{array}$ & $\begin{array}{l}-0,064 \\
(-7,373) \\
\end{array}$ & $\begin{array}{l}-0,008 \\
(-1,365) \\
\end{array}$ & $\begin{array}{c}0,008 \\
(0,731) \\
\end{array}$ & $\begin{array}{l}-0,015 \\
(-2,655) \\
\end{array}$ & $\begin{array}{l}-0,035 \\
(-2,634) \\
\end{array}$ & $\begin{array}{c}0,008 \\
(0,731)\end{array}$ \\
\hline $\begin{array}{l}\text { 5-10 eFt kategória } \\
\text { logaritmusának négyzete }\end{array}$ & $\begin{array}{l}-0,048 \\
(-5,368)\end{array}$ & $\begin{array}{c}-0,032 \\
(-5,265)\end{array}$ & $\begin{array}{c}0,001 \\
(0,065)\end{array}$ & $\begin{array}{l}-0,029 \\
(-5,207)\end{array}$ & $\begin{array}{l}-0,051 \\
(-3,522)\end{array}$ & $\begin{array}{c}0,001 \\
(0,065)\end{array}$ \\
\hline $\begin{array}{l}\text { 10-20 eFt kategória } \\
\text { logaritmusának négyzete }\end{array}$ & $\begin{array}{c}0,092 \\
(10,018) \\
\end{array}$ & $\begin{array}{c}0,054 \\
(8,656)\end{array}$ & $\begin{array}{c}0,026 \\
(2,394)\end{array}$ & $\begin{array}{c}0,055 \\
(8,935) \\
\end{array}$ & $\begin{array}{c}0,085 \\
(6,737)\end{array}$ & $\begin{array}{c}0,026 \\
(2,394)\end{array}$ \\
\hline $\begin{array}{l}\text { 20- eFt kategória } \\
\text { logaritmusának négyzete }\end{array}$ & $\begin{array}{l}-0,065 \\
(-7,595) \\
\end{array}$ & $\begin{array}{l}-0,058 \\
(-9,370) \\
\end{array}$ & $\begin{array}{l}-0,052 \\
(-4,435) \\
\end{array}$ & $\begin{array}{l}-0,064 \\
(-9,987)\end{array}$ & $\begin{array}{l}-0,047 \\
(-4,774)\end{array}$ & $\begin{array}{l}-0,052 \\
(-4,435)\end{array}$ \\
\hline Átlagos tételszám & $\begin{array}{l}-0,013 \\
(-0,825)\end{array}$ & $\begin{array}{l}-0,033 \\
(-2,366)\end{array}$ & $\begin{array}{l}-0,023 \\
(-1,012)\end{array}$ & $\begin{array}{l}-0,070 \\
(-5,476)\end{array}$ & $\begin{array}{c}0,106 \\
(4,944)\end{array}$ & $\begin{array}{l}-0,023 \\
(-1,012) \\
\end{array}$ \\
\hline Átlagos fizetési érték & $\begin{array}{c}0,000 \\
(-2,677) \\
\end{array}$ & $\begin{array}{c}0,000 \\
(-2,184) \\
\end{array}$ & $\begin{array}{c}0,000 \\
(-1,011) \\
\end{array}$ & $\begin{array}{c}0,000 \\
(-7,004) \\
\end{array}$ & $\begin{array}{c}0,000 \\
(-1,184) \\
\end{array}$ & $\begin{array}{c}0,000 \\
(-1,011)\end{array}$ \\
\hline 0-1 eFt kategória aránya & $\begin{array}{l}-2,008 \\
(-2,555)\end{array}$ & $\begin{array}{l}-1,036 \\
(-2,220)\end{array}$ & $\begin{array}{c}0,463 \\
(0,497)\end{array}$ & $\begin{array}{l}-2,572 \\
(-5,722)\end{array}$ & $\begin{array}{c}1,290 \\
(1,060)\end{array}$ & $\begin{array}{c}0,463 \\
(0,497)\end{array}$ \\
\hline 1-5 eFt kategória aránya & $\begin{array}{l}-3,400 \\
(-4,110) \\
\end{array}$ & $\begin{array}{l}-1,808 \\
(-3,631) \\
\end{array}$ & $\begin{array}{l}-0,981 \\
(-0,981) \\
\end{array}$ & $\begin{array}{l}-2,164 \\
(-4,403) \\
\end{array}$ & $\begin{array}{l}-2,756 \\
(-2,188) \\
\end{array}$ & $\begin{array}{c}-0,981 \\
(-0,981)\end{array}$ \\
\hline 5-10 eFt kategória aránya & $\begin{array}{c}4,393 \\
(4,140)\end{array}$ & $\begin{array}{c}3,128 \\
(5,004)\end{array}$ & $\begin{array}{c}3,105 \\
(2,741)\end{array}$ & $\begin{array}{c}2,482 \\
(4,235) \\
\end{array}$ & $\begin{array}{c}1,841 \\
(1,028)\end{array}$ & $\begin{array}{c}3,105 \\
(2,741) \\
\end{array}$ \\
\hline 10-20 eFt kategória aránya & $\begin{array}{c}1,933 \\
(2,149)\end{array}$ & $\begin{array}{c}0,103 \\
(0,211)\end{array}$ & $\begin{array}{l}2,502 \\
(2,381)\end{array}$ & $\begin{array}{c}0,312 \\
(0,637)\end{array}$ & $\begin{array}{c}5,049 \\
(3,126)\end{array}$ & $\begin{array}{c}2,502 \\
(2,381)\end{array}$ \\
\hline $\begin{array}{l}0-1 \text { eFt kategória arány } \\
\text { négyzete }\end{array}$ & $\begin{array}{l}-5,652 \\
(-8,423)\end{array}$ & $\begin{array}{l}-3,665 \\
(-8,657)\end{array}$ & $\begin{array}{l}-3,602 \\
(-4,540)\end{array}$ & $\begin{array}{l}-2,857 \\
(-7,256)\end{array}$ & $\begin{array}{l}-5,903 \\
(-5,353)\end{array}$ & $\begin{array}{l}-3,602 \\
(-4,540)\end{array}$ \\
\hline $\begin{array}{l}\text { 1-5 eFt kategória arány } \\
\text { négyzete }\end{array}$ & $\begin{array}{c}3,370 \\
(4,740)\end{array}$ & $\begin{array}{c}0,317 \\
(0,723)\end{array}$ & $\begin{array}{c}0,820 \\
(0,954) \\
\end{array}$ & $\begin{array}{c}0,414 \\
(1,013)\end{array}$ & $\begin{array}{c}5,203 \\
(4,558)\end{array}$ & $\begin{array}{c}0,820 \\
(0,954)\end{array}$ \\
\hline $\begin{array}{l}\text { 5-10 eFt kategória arány } \\
\text { négyzete }\end{array}$ & $\begin{array}{l}-9,655 \\
(-5,470) \\
\end{array}$ & $\begin{array}{l}-8,170 \\
(-8,180)\end{array}$ & $\begin{array}{l}-6,807 \\
(-3,910) \\
\end{array}$ & $\begin{array}{l}-7,127 \\
(-7,471)\end{array}$ & $\begin{array}{l}-1,559 \\
(-0,587)\end{array}$ & $\begin{array}{l}-6,807 \\
(-3,910)\end{array}$ \\
\hline $\begin{array}{l}10-20 \text { eFt kategória arány } \\
\text { négyzete }\end{array}$ & $\begin{array}{l}-4,154 \\
(-4,003) \\
\end{array}$ & $\begin{array}{l}-1,730 \\
(-3,146) \\
\end{array}$ & $\begin{array}{l}-3,640 \\
(-3,030)\end{array}$ & $\begin{array}{l}-2,177 \\
(-3,913) \\
\end{array}$ & $\begin{array}{l}-5,645 \\
(-2,469) \\
\end{array}$ & $\begin{array}{l}-3,640 \\
(-3,030)\end{array}$ \\
\hline Hálózat teljes bevétele & $\begin{array}{c}1,135 \\
(5,017)\end{array}$ & $\begin{array}{r}-375,069 \\
(-1,330) \\
\end{array}$ & $\begin{array}{c}-5,483 \\
(-12,420) \\
\end{array}$ & $\begin{array}{l}-0,798 \\
(-3,966)\end{array}$ & $\begin{array}{c}1,601 \\
(4,326)\end{array}$ & $\begin{array}{c}-5,483 \\
(-12,420) \\
\end{array}$ \\
\hline $\begin{array}{l}\text { Hálózat teljes bevételének } \\
\text { négyzete }\end{array}$ & $\begin{array}{l}-0,006 \\
(-1,105)\end{array}$ & $\begin{array}{l}11,003 \\
(1,360)\end{array}$ & $\begin{array}{c}0,128 \\
(11,098)\end{array}$ & $\begin{array}{c}0,028 \\
(5,306)\end{array}$ & $\begin{array}{l}-0,035 \\
(-3,951) \\
\end{array}$ & $\begin{array}{c}0,128 \\
(11,098)\end{array}$ \\
\hline Hálózati boltok száma & $\begin{array}{c}-0,023 \\
(-20,990) \\
\end{array}$ & $\begin{array}{c}0,000 \\
(0,000)\end{array}$ & $\begin{array}{c}0,004 \\
(1,291)\end{array}$ & $\begin{array}{l}-0,003 \\
(-4,493) \\
\end{array}$ & $\begin{array}{c}0,031 \\
(12,147) \\
\end{array}$ & $\begin{array}{c}0,004 \\
(1,291)\end{array}$ \\
\hline $\begin{array}{l}\text { Hálózati boltok számának } \\
\text { négyzete }\end{array}$ & $\begin{array}{c}0,000 \\
(19,004)\end{array}$ & $\begin{array}{c}0,000 \\
(0,000)\end{array}$ & $\begin{array}{c}0,000 \\
(-1,064)\end{array}$ & $\begin{array}{c}0,000 \\
(3,750)\end{array}$ & $\begin{array}{c}0,000 \\
(-18,701)\end{array}$ & $\begin{array}{c}0,000 \\
(-1,064)\end{array}$ \\
\hline
\end{tabular}




\begin{tabular}{|c|c|c|c|c|c|c|}
\hline & $\begin{array}{l}\text { Hálózati } \\
\text { döntésú } \\
\text { üzletek }\end{array}$ & $\begin{array}{l}\text { Egyedi } \\
\text { üzletek }\end{array}$ & $\begin{array}{l}\text { Egyedi } \\
\text { döntésú } \\
\text { üzletek }\end{array}$ & $\begin{array}{c}\text { Kis } \\
\text { méretű } \\
\text { üzletek }\end{array}$ & $\begin{array}{c}\text { Közepes } \\
\text { méretú } \\
\text { üzletek }\end{array}$ & $\begin{array}{c}\text { Nagy } \\
\text { méretű } \\
\text { üzletek }\end{array}$ \\
\hline Hétfői zárvatartás & $\begin{array}{c}-0,642 \\
(-7,025)\end{array}$ & $\begin{array}{c}-0,570 \\
(-11,195)\end{array}$ & $\begin{array}{c}-0,728 \\
(-7,562)\end{array}$ & $\begin{array}{c}-0,675 \\
(-13,897)\end{array}$ & $\begin{array}{c}-0,490 \\
(-3,012)\end{array}$ & $\begin{array}{c}-0,728 \\
(-7,562)\end{array}$ \\
\hline Keddi zárvatartás & $\begin{array}{c}-0,792 \\
(-5,903)\end{array}$ & $\begin{array}{c}-0,592 \\
(-7,811)\end{array}$ & $\begin{array}{c}-1,067 \\
(-7,190)\end{array}$ & $\begin{array}{c}-0,779 \\
(-10,764)\end{array}$ & $\begin{array}{c}-0,728 \\
(-3,279)\end{array}$ & $\begin{array}{c}-1,067 \\
(-7,190)\end{array}$ \\
\hline Vasárnapi zárvatartás & $\begin{array}{c}0,126 \\
(2,759)\end{array}$ & $\begin{array}{c}-0,115 \\
(-3,967)\end{array}$ & $\begin{array}{c}0,025 \\
(0,493)\end{array}$ & $\begin{array}{c}-0,023 \\
(-0,882)\end{array}$ & $\begin{array}{c}-0,078 \\
(-1,287)\end{array}$ & $\begin{array}{c}0,025 \\
(0,493)\end{array}$ \\
\hline Megye: Mozgóbolt & $\begin{array}{c}-0,677 \\
(-3,299)\end{array}$ & $\begin{array}{c}-0,838 \\
(-6,668)\end{array}$ & $\begin{array}{c}-0,920 \\
(-4,499)\end{array}$ & $\begin{array}{c}-0,708 \\
(-6,537)\end{array}$ & $\begin{array}{c}-1,039 \\
(-3,925)\end{array}$ & $\begin{array}{c}-0,920 \\
(-4,499)\end{array}$ \\
\hline Megye: Bács-Kiskun & $\begin{array}{c}0,608 \\
(5,656)\end{array}$ & $\begin{array}{c}0,321 \\
(4,920)\end{array}$ & $\begin{array}{c}0,229 \\
(1,955)\end{array}$ & $\begin{array}{c}0,447 \\
(7,562)\end{array}$ & $\begin{array}{c}0,054 \\
(0,326)\end{array}$ & $\begin{array}{c}0,229 \\
(1,955)\end{array}$ \\
\hline Megye: Baranya & $\begin{array}{c}0,364 \\
(2,693) \\
\end{array}$ & $\begin{array}{c}-0,075 \\
(-0,874)\end{array}$ & $\begin{array}{c}0,200 \\
(1,369)\end{array}$ & $\begin{array}{c}0,198 \\
(2,650)\end{array}$ & $\begin{array}{c}-0,237 \\
(-1,116)\end{array}$ & $\begin{array}{c}0,200 \\
(1,369)\end{array}$ \\
\hline Megye: Békés & $\begin{array}{c}-0,328 \\
(-2,559)\end{array}$ & $\begin{array}{c}-0,622 \\
(-7,639)\end{array}$ & $\begin{array}{c}-0,473 \\
(-3,487)\end{array}$ & $\begin{array}{c}-0,445 \\
(-6,235)\end{array}$ & $\begin{array}{c}-0,748 \\
(-4,074)\end{array}$ & $\begin{array}{c}-0,473 \\
(-3,487)\end{array}$ \\
\hline Megye: Borsod-Abaúj-Zemplén & $\begin{array}{c}-0,137 \\
(-0,971)\end{array}$ & $\begin{array}{c}-0,578 \\
(-6,187)\end{array}$ & $\begin{array}{c}-0,410 \\
(-2,796)\end{array}$ & $\begin{array}{c}-0,351 \\
(-4,420)\end{array}$ & $\begin{array}{c}-0,378 \\
(-1,818)\end{array}$ & $\begin{array}{c}-0,410 \\
(-2,796)\end{array}$ \\
\hline Megye: Budapest & $\begin{array}{c}-0,293 \\
(-2,249)\end{array}$ & $\begin{array}{c}-0,131 \\
(-1,646)\end{array}$ & $\begin{array}{c}-0,359 \\
(-2,686)\end{array}$ & $\begin{array}{c}-0,158 \\
(-2,228)\end{array}$ & $\begin{array}{c}-0,643 \\
(-3,372)\end{array}$ & $\begin{array}{c}-0,359 \\
(-2,686)\end{array}$ \\
\hline Megye: Csongrád & $\begin{array}{c}0,307 \\
(2,338)\end{array}$ & $\begin{array}{c}0,022 \\
(0,263)\end{array}$ & $\begin{array}{c}0,157 \\
(1,135)\end{array}$ & $\begin{array}{c}0,225 \\
(3,104)\end{array}$ & $\begin{array}{c}-0,365 \\
(-1,878)\end{array}$ & $\begin{array}{c}0,157 \\
(1,135)\end{array}$ \\
\hline Megye: Fejér & $\begin{array}{c}0,496 \\
(3,670)\end{array}$ & $\begin{array}{c}0,064 \\
(0,762)\end{array}$ & $\begin{array}{c}0,179 \\
(1,182)\end{array}$ & $\begin{array}{c}0,291 \\
(3,914)\end{array}$ & $\begin{array}{c}-0,184 \\
(-0,905)\end{array}$ & $\begin{array}{c}0,179 \\
(1,182)\end{array}$ \\
\hline Megye: Győr-Moson-Sopron & $\begin{array}{c}-0,173 \\
(-1,356)\end{array}$ & $\begin{array}{c}-0,532 \\
(-6,745)\end{array}$ & $\begin{array}{c}-0,540 \\
(-3,950)\end{array}$ & $\begin{array}{c}-0,351 \\
(-4,971)\end{array}$ & $\begin{array}{c}-0,883 \\
(-4,901)\end{array}$ & $\begin{array}{c}-0,540 \\
(-3,950)\end{array}$ \\
\hline Megye: Hajdú-Bihar & $\begin{array}{c}0,133 \\
(1,060)\end{array}$ & $\begin{array}{c}-0,108 \\
(-1,342)\end{array}$ & $\begin{array}{c}0,030 \\
(0,222)\end{array}$ & $\begin{array}{c}-0,014 \\
(-0,200)\end{array}$ & $\begin{array}{c}-0,231 \\
(-1,200)\end{array}$ & $\begin{array}{c}0,030 \\
(0,222)\end{array}$ \\
\hline Megye: Heves & $\begin{array}{c}0,095 \\
(0,636)\end{array}$ & $\begin{array}{c}-0,148 \\
(-1,661)\end{array}$ & $\begin{array}{c}-0,168 \\
(-1,137)\end{array}$ & $\begin{array}{c}0,054 \\
(0,678)\end{array}$ & $\begin{array}{c}-0,211 \\
(-1,008)\end{array}$ & $\begin{array}{c}-0,168 \\
(-1,137)\end{array}$ \\
\hline Megye: Jász-Nagykun-Szolnok & $\begin{array}{c}0,675 \\
(4,815)\end{array}$ & $\begin{array}{c}0,180 \\
(2,028)\end{array}$ & $\begin{array}{c}0,289 \\
(1,864)\end{array}$ & $\begin{array}{c}0,501 \\
(6,284)\end{array}$ & $\begin{array}{c}0,308 \\
(1,370) \\
\end{array}$ & $\begin{array}{c}0,289 \\
(1,864)\end{array}$ \\
\hline Megye: Komárom-Esztergom & $\begin{array}{c}0,062 \\
(0,373)\end{array}$ & $\begin{array}{c}-0,566 \\
(-4,562)\end{array}$ & $\begin{array}{c}-0,669 \\
(-3,595)\end{array}$ & $\begin{array}{c}-0,316 \\
(-3,094)\end{array}$ & $\begin{array}{c}-0,394 \\
(-1,553)\end{array}$ & $\begin{array}{c}-0,669 \\
(-3,595)\end{array}$ \\
\hline Megye: Nógrád & $\begin{array}{c}0,267 \\
(2,339)\end{array}$ & $\begin{array}{c}-0,109 \\
(-1,573)\end{array}$ & $\begin{array}{c}0,033 \\
(0,265)\end{array}$ & $\begin{array}{c}0,094 \\
(1,487)\end{array}$ & $\begin{array}{c}-0,379 \\
(-2,211)\end{array}$ & $\begin{array}{c}0,033 \\
(0,265)\end{array}$ \\
\hline Megye: Pest & $\begin{array}{c}-0,320 \\
(-2,239)\end{array}$ & $\begin{array}{c}-0,340 \\
(-3,693)\end{array}$ & $\begin{array}{c}-0,249 \\
(-1,562)\end{array}$ & $\begin{array}{c}-0,288 \\
(-3,564)\end{array}$ & $\begin{array}{c}-0,540 \\
(-2,555)\end{array}$ & $\begin{array}{c}-0,249 \\
(-1,562)\end{array}$ \\
\hline Megye: Somogy & $\begin{array}{c}-0,818 \\
(-6,036)\end{array}$ & $\begin{array}{c}-0,772 \\
(-8,841)\end{array}$ & $\begin{array}{c}-0,839 \\
(-5,983)\end{array}$ & $\begin{array}{c}-0,761 \\
(-10,018)\end{array}$ & $\begin{array}{c}-1,007 \\
(-5,208)\end{array}$ & $\begin{array}{c}-0,839 \\
(-5,983)\end{array}$ \\
\hline $\begin{array}{l}\text { Megye: Szabolcs-Szatmár- } \\
\text { Bereg }\end{array}$ & $\begin{array}{c}0,008 \\
(0,054)\end{array}$ & $\begin{array}{l}-0,380 \\
(-4,247)\end{array}$ & $\begin{array}{l}-0,104 \\
(-0,725)\end{array}$ & $\begin{array}{l}-0,147 \\
(-1,912)\end{array}$ & $\begin{array}{l}-0,520 \\
(-2,524)\end{array}$ & $\begin{array}{l}-0,104 \\
(-0,725)\end{array}$ \\
\hline Megye: Tolna & $\begin{array}{c}0,053 \\
(0,345)\end{array}$ & $\begin{array}{l}-0,341 \\
(-3,378)\end{array}$ & $\begin{array}{c}-0,137 \\
(-0,884)\end{array}$ & $\begin{array}{l}-0,084 \\
(-0,991)\end{array}$ & $\begin{array}{l}-0,416 \\
(-1,785)\end{array}$ & $\begin{array}{l}-0,137 \\
(-0,884)\end{array}$ \\
\hline
\end{tabular}


A kereskedők fizetésikártya-elfogadása Magyarországon az online pénztárgépek...

\begin{tabular}{l|c|c|c|c|c|c}
\hline & $\begin{array}{c}\text { Hálózati } \\
\text { döntésú } \\
\text { üzletek }\end{array}$ & $\begin{array}{c}\text { Egyedi } \\
\text { üzletek }\end{array}$ & $\begin{array}{c}\text { Egyedi } \\
\text { döntésű } \\
\text { üzletek }\end{array}$ & $\begin{array}{c}\text { Kis } \\
\text { méretú } \\
\text { üzletek }\end{array}$ & $\begin{array}{c}\text { Közepes } \\
\text { méretú } \\
\text { üzletek }\end{array}$ & $\begin{array}{c}\text { Nagy } \\
\text { méretú } \\
\text { üzletek }\end{array}$ \\
\hline Megye: Vas & $\begin{array}{c}-0,382 \\
(-2,674)\end{array}$ & $\begin{array}{c}-0,660 \\
(-6,643)\end{array}$ & $\begin{array}{c}-0,671 \\
(-4,377)\end{array}$ & $\begin{array}{c}-0,550 \\
(-6,580)\end{array}$ & $\begin{array}{c}-0,754 \\
(-3,653)\end{array}$ & $\begin{array}{c}-0,671 \\
(-4,377)\end{array}$ \\
\hline Megye: Veszprém & $\begin{array}{c}0,475 \\
(3,540)\end{array}$ & $\begin{array}{c}0,024 \\
(0,293)\end{array}$ & $\begin{array}{c}0,061 \\
(0,428)\end{array}$ & $\begin{array}{c}0,233 \\
(3,161)\end{array}$ & $\begin{array}{c}-0,142 \\
(-0,691)\end{array}$ & $\begin{array}{c}0,061 \\
(0,428)\end{array}$ \\
\hline Megye: Zala & \multicolumn{7}{|l|}{} & & & & \\
\hline
\end{tabular}

